\title{
Review of the mudflat varunid crab genus Metaplax (Crustacea, Brachyura, Varunidae) from East Asia and northern Vietnam
}

\author{
Hsi-Te Shih ${ }^{1,2, *}$ Jhih-Wei Hsu ${ }^{\text {1,* }}$ Kingsley J.H. Wong ${ }^{3}, \mathrm{Ngan} \mathrm{Kee} \mathrm{Ng}^{4}$ \\ I Department of Life Science, National Chung Hsing University, Taichung 402, Taiwan 2 Research Center \\ for Global Change Biology, National Chung Hsing University, Taichung 402, Taiwan 3 Biodiversity Research \\ Center, Academia Sinica, Taipei 115, Taiwan 4 Department of Biological Sciences, National University of \\ Singapore, 117543, Singapore
}

Corresponding author: Hsi-Te Shih (htshih@dragon.nchu.edu.tw)

Academic editor: Sammy De Grave | Received 16 July 2019 | Accepted 30 August 2019 | Published 2 October 2019

http://zoobank.org/399DB9F8-FFD1-4F92-B091-7CC9B17B5F48

Citation: Shih H-T, Hsu J-W, Wong KJH, Ng NK (2019) Review of the mudflat varunid crab genus Metaplax (Crustacea, Brachyura, Varunidae) from East Asia and northern Vietnam. ZooKeys 877: 1-29. https://doi.org/10.3897/ zookeys. 877.38300

\begin{abstract}
Intertidal mudflat crabs of the genus Metaplax H. Milne Edwards, 1852 (Crustacea: Brachyura: Varunidae) from China, Taiwan, and northern Vietnam are taxonomically revised by morphological and molecular evidence. These crabs show sexual dimorphism and morphological variation of a considerable range in the infraorbital ridge, one of the primary features previously used for species identification. In this study, four species were identified from the region: M. elegans De Man, 1888; M. longipes Stimpson, 1858; M. sheni Gordon, 1930; and M. tredecim Tweedie, 1950. Based on the results of the morphological examination, and as confirmed by molecular evidence from mitochondrial cytochrome oxidase subunit I (COI), taxonomic confusion surrounding M. longipes was resolved, and M. takahasii Sakai, 1939, is considered a junior synonym of $M$. longipes. The geographical distribution of Metaplax longipes extends along the shores of China, north to Jiangsu, whereas the Southeast Asian M. tredecim was newly recorded from northern Vietnam and Hong Kong.
\end{abstract}

\footnotetext{
* These authors contributed equally to this paper
}

Copyright Hsi-Te Shih et al. This is an open access article distributed under the terms of the Creative Commons Attribution License (CC BY 4.0), which permits unrestricted use, distribution, and reproduction in any medium, provided the original author and source are credited. 


\section{Keywords}

COI, Metaplax elegans, M. longipes, M. sheni, M. takahasii, M. tredecim, mitochondrial cytochrome oxidase subunit I, morphology

\section{Introduction}

Indo-West Pacific varunid crabs of the genus Metaplax H. Milne Edwards, 1852 commonly inhabit sheltered shores with silty muddy substrate often near or under shades of mangroves in tropical and subtropical regions. While some studies have reported on various biological aspects of selected species (e.g., Macnae 1963; Beinlich and Polivka 1989; Chakraborty and Choudhury 1994), the phylogenetic position of this group within the Thoracotremata remains obscure due to limited taxon sampling (see Kitaura et al. 2002; Chen et al. 2019; Liu et al. 2019).

Species of the genus Metaplax all share a broad, subquadrate, somewhat depressed carapace, which is shallowly marked, broad fronted (approximately $1 / 3$ carapace width), and has lateral margins bearing at most five distinct teeth; slender and elongated ambulatory legs are also shared. One of the frequently used morphological features for species identification remains the number of lobes and tubercles along the infraorbital ridge (Tesch 1918; Tweedie 1950; Dai et al. 1986; Dai and Yang 1991), which are sexually dimorphic as in many varunid groups. The infraorbital tubercles are reported to serve a stridulatory function, which engage with the ridge along the anterior margin of the chelipedal merus (Macnae 1963; Beinlich and Polivka 1989). Metaplax contains around 12 species ( $\mathrm{Ng}$ et al. 2008; but see Naderloo 2011 on the identity of $M$. indicus occidentalis Pretzmann, 1971), with an overall distribution extending from the shores of the Persian Gulf, the Arabian Sea, the Bay of Bengal to Southeast and East Asia, and easternmost to western Taiwan. Six species, namely $M$. elegans De Man, 1888; $M$. gocongensis Davie \& Nguyen, 2003; M. longipes Stimpson, 1858; M. sheni Gordon, 1930; M. takahasii Sakai, 1939; and M. tredecim Tweedie, 1950, have been recorded from East and Southeast Asia, with only $M$. elegans recorded in the eastern Indian Ocean as well (De Man 1888; Ng and Davie 2002; Dev Roy and Bhadra 2011).

In East Asia, the northern limit of this genus appears to be around Zhejiang, China (Dai et al. 1986; Chen 1991; Dai and Yang 1991). Metaplax is absent from the east coast of Taiwan, the Ryukyus, the main islands of Japan, and Korea (Sakai 1939, 1940, 1976). Five species were previously reported from the region, including $M$. elegans De Man, 1888, M. longipes Stimpson, 1858, M. sheni Gordon, 1930, M. takahasii Sakai, 1939, and M. tredecim Tweedie, 1950. Among these, M. takahasii has been considered a junior synonym of $M$. longipes (see Davie and Nguyen 2003), whereas tropical $M$. tredecim had been first listed as part of the fauna of the East China and South China seas by Yang et al. (2008) without any illustration or elaboration.

In the present study, specimens of species of Metaplax were collected from various sites in East Asia (Fig. 1), their morphological features are examined and illustrated, and identifications are confirmed by molecular evidence from mitochondrial cytochrome oxidase subunit I (COI). 


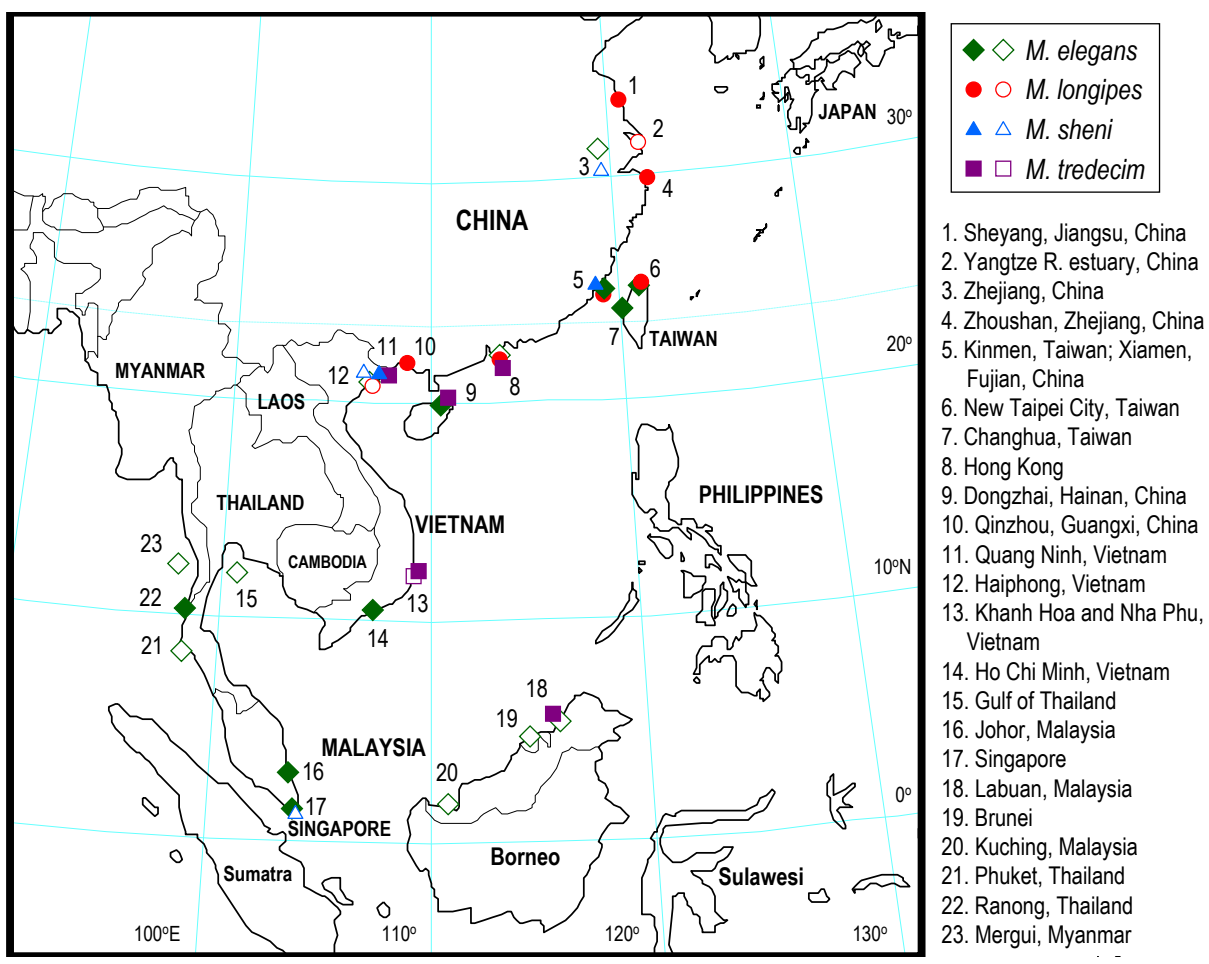

Figure I. Collection sites (solid symbols) for species of the genus Metaplax used in this study: green rhombus for $M$. elegans; red circles for $M$. longipes; blue triangles for $M$. sheni; and purple squares for $M$. tredecim. Empty symbols mean the additional records from references (see synonym lists for each species).

\section{Materials and methods}

Specimens were collected from China, Taiwan, and Vietnam (Table 1, Fig. 1) and have been deposited in the Kanagawa Prefectural Museum of Natural History, Kanagawa, Japan (KPM-NH); the Zoological Collections of the Department of Life Science, National Chung Hsing University, Taichung, Taiwan (NCHUZOOL), and the Zoological Reference Collection of the Lee Kong Chian Natural History Museum, National University of Singapore, Singapore (ZRC). The abbreviation G1 is used for male first gonopods. Measurement is of the maximum carapace width (CW) in millimeters.

To understand whether the number of infraorbital tubercles and lobes of each species is related to the sex and body size, the numbers on both sides for each specimen were calculated, averaged, and plotted against CWs. Specimens used were 21 males (CW 7.7-15.9 mm) and 19 females (CW 6.3-13.2 mm) for M. elegans, 69 males (CW 6.8-26.6 mm) and 29 females (CW 7.9-23.6 mm) for M. longipes, 7 males (CW 8.6-12.8 mm) for M. sheni (no female specimen), and 23 males (CW 12.8-22.7 mm) and 13 females (CW 10.3-23.4 mm) for M. tredecim.

Genomic DNA was isolated from the muscle tissue using extraction kits following Shih et al. (2016). A portion of the COI gene was amplified with PCR using the primers 
Table I. The haplotypes and accession numbers (DNA Data Bank of Japan) of the COI gene of Metaplax specimens and outgroups from East Asia and northern Vietnam. For abbreviations of museums and universities, see Materials and methods.

\begin{tabular}{|c|c|c|c|c|c|}
\hline Species & Locality & $\begin{array}{l}\text { Sample } \\
\text { size }\end{array}$ & $\begin{array}{l}\text { Catalogue no. of } \\
\text { NCHUZOOL (unless } \\
\text { indicated) }\end{array}$ & $\begin{array}{l}\text { Haplotype } \\
\text { of COI }\end{array}$ & $\begin{array}{l}\text { Access. no. } \\
\text { of COI }\end{array}$ \\
\hline \multirow[t]{5}{*}{ M. elegans } & Taiwan: Jhuwei, New Taipei City & 1 & 15480 & MXe1 & LC498179 \\
\hline & Taiwan: Kinmen & 1 & 15489 & MXe2 & LC498180 \\
\hline & Vietnam: Ho Chi Minh City & 1 & 15499 & MXe3 & LC498181 \\
\hline & Singapore: Sungei Buloh & 1 & ZRC 1997.683 & MXe4 & LC498182 \\
\hline & Thailand: Ranong & 1 & 15494 & MXe4 & LC498182 \\
\hline \multirow[t]{8}{*}{ M. longipes } & Taiwan: Danshuei, New Taipei City & 1 & NTOU & MXL2 & LC498183 \\
\hline & Taiwan: Danshuei, New Taipei City & 1 & ZRC 1999.0708 & MXL2 & LC498183 \\
\hline & Taiwan: Kinmen & 1 & 15460 & MXL2 & LC498183 \\
\hline & Taiwan: Kinmen & 1 & 15462 & MXL2 & LC498183 \\
\hline & China: Zhoushan, Zhejiang & 2 & $15466 ; 15465$ & MXL2 & LC498183 \\
\hline & China: Xiamen, Fujian & 1 & 15475 & MXL2 & LC498183 \\
\hline & China: Qinzhou, Guangxi & 1 & 15449 & MXL3 & LC498185 \\
\hline & Hong Kong: Tung Chung & 1 & 15450 & MXL1 & LC498184 \\
\hline \multirow[t]{3}{*}{ M. sheni } & Taiwan: Kinmen & 1 & 15467 & MXs1 & LC498186 \\
\hline & China: Xiamen, Fujian & 2 & 15465 & $\begin{array}{l}\text { MXs1, } \\
\text { MXs2 }\end{array}$ & $\begin{array}{l}\text { LC498186, } \\
\text { LC498187 }\end{array}$ \\
\hline & Vietnam: Dong Rui, Quang Ninh & 1 & 15466 & MXs1 & LC498186 \\
\hline \multirow[t]{4}{*}{ M. tredecim } & Hong Kong: Nai Chung & 1 & 15472 & MXt1 & LC498188 \\
\hline & Vietnam: Dong Rui, Quang Ninh & 1 & 15477 & $\mathrm{MXt} 2$ & LC498189 \\
\hline & Vietnam: Nha Trang & 1 & 15498 & MXt3 & LC498190 \\
\hline & Malaysia: Labuan & 1 & 15475 & MXt4 & LC498191 \\
\hline Total & & 22 & & & \\
\hline \multicolumn{6}{|l|}{ Outgroups } \\
\hline Gaetice depressus & Taiwan: Keelung & & 15544 & & LC498192 \\
\hline Helice formosensis & Taiwan: Shengang, Changhua & & 13083 & & AB334543 \\
\hline $\begin{array}{l}\text { Hemigrapsus } \\
\text { sanguineus }\end{array}$ & Taiwan: Yongsing, New Taipei City & & 15545 & & LC498193 \\
\hline Varuna litterata & Taiwan: Kenting, Pingtung & & 14816 & & LC498194 \\
\hline
\end{tabular}

LCO1490 and HCO2198 (Folmer et al. 1994). PCR conditions for the above primers were denaturation for $50 \mathrm{~s}$ at $94^{\circ} \mathrm{C}$, annealing for $70 \mathrm{~s}$ at $45-47^{\circ} \mathrm{C}$, and extension for $60 \mathrm{~s}$ at $72{ }^{\circ} \mathrm{C}$ ( 40 cycles), followed by extension for $10 \mathrm{~min}$ at $72^{\circ} \mathrm{C}$. Sequences were obtained by automated sequencing (Applied Biosystems 3730), after verification with the complementary strand. Sequences of the different haplotypes have been deposited in the DNA Data Bank of Japan (DDBJ) (accession numbers are shown in Table 1). Outgroups were selected based on the phylogenetic tree of Kitaura et al. (2002: Fig. 2), as follows: Gaetice depressus (De Haan, 1835); Helice formosensis Rathbun, 1931; Hemigrapsus sanguineus (De Haan, 1835); and Varuna litterata (Fabricius, 1798).

The best-fitting model of sequence evolution was determined by PartitionFinder (ver. 2.1.1; Lanfear et al. 2017) and selected by the Bayesian information criterion (BIC). The obtained best model $(\mathrm{GTR}+\mathrm{I}+\mathrm{G})$ was subsequently used for a Bayesian inference (BI) analysis. BI analysis was performed with MrBayes (ver. 3.2.3, Ronquist et al. 2012). Phylogenetic analysis was performed with four chains for 10 million 
generations and four independent runs, with trees sampled every 1000 generations. The convergence of chains was determined by the average standard deviation of split frequency values below the recommended 0.01 (Ronquist et al. 2019), and the first 1000 trees were discarded as the burnin accordingly. Maximum likelihood (ML) analysis was conducted using RAxML (vers. 7.2.6, Stamatakis 2006). The model GTR + G (i.e. GTRGAMMA) was used with 100 runs and finding the best ML tree by comparing the likelihood scores. The robustness of the ML tree was evaluated by 1000 bootstrap pseudoreplicates under the model GTRGAMMA. Base pair (bp) differences and pairwise estimates of Kimura 2-parameter (K2P) distances (Kimura 1980) for genetic diversities between specimens were calculated with MEGA (ver. 10.0.5, Kumar et al. 2018).

\section{Results}

\section{Systematics}

\section{Family Varunidae H. Milne Edwards, 1853 \\ Genus Metaplax H. Milne Edwards, 1852}

\section{Metaplax elegans De Man, 1888}

Figures 2A-C, 3, 7A-D

Metaplax elegans De Man, 1888: 164, pl. 11(4-6) (type locality: Mergui, Myanmar); Alcock 1900: 434 (East India: Godavari Delta; Myanmar: Mergui); Gordon 1931: 528 (Hong Kong); Rathbun 1931: 100 (China: Fujian; Guangdong); Tweedie 1936: 69 (Malaysia: Selangor; Singapore); Shen 1940a: 74, 95 (China: Zhejiang; Fujian); Shen 1940b: 236 (Hong Kong); Tweedie 1950: 353 (Malaysia: Labuan; Kuching); Macnae 1963: 104, 180 (list); Dai et al. 1986: 509, fig. 289 (1-2), pl. 72(5) (China: Guangdong); Fukui et al. 1989: 230, fig. 25 (W Taiwan); Dai and Yang 1991: 557, fig. 289 (1-2), pl. 72(5) (China: Guangdong); J.-T. Shih et al. 1991: 126 (Taiwan: New Taipei City); Davie 1992: 352, pl. 2B (Hong Kong); Choy and Booth 1994: 243 (Brunei); Huang 1994: 598 (list; China); Tan and Ng 1994: 82 (Singapore; Malaysia); Kuo 1995: 31, 82, 97, 191, 4 unnumbered figs (W Taiwan); Wang and Liu 1996a: 128, figs 171-172 (W Taiwan); Wang and Liu 1996b: 103-104, 2 unnumbered figs (W Taiwan); Fransen et al. 1997: 125 (syntype; Mergui, Myanmar); Ho and Hung 1997: 108-109, 1 unnumbered fig.; Kosuge et al. 1997: 182 (Vietnam: Haiphong); Jeng et al. 1998: 68, 3 unnumbered figs (Taiwan: Taichung); Wang and Liu 1998a: 128, figs 171-172 (W Taiwan); Wang and Liu 1998b: 142, 2 unnumbered figs (W Taiwan); Lee and Leung 1999: 68, pl. 11 (Hong Kong); Ng and Sivasothi 1999: 73, 2 unnumbered figs (Singapore); Jeng and Wang 2000: 38, 2 unnumbered figs (Taiwan: Taichung); Lee and Tung 2000: 70 (list); Dev Roy and Bhadra 2011: 36 (list; E India); Lee 2001: 
114, 3 unnumbered figs (W Taiwan); $\mathrm{Ng}$ et al. 2001: 45 (list; Taiwan); Kitaura et al. 2002: 684 (Vietnam: Haiphong); Ng and Davie 2002: 379 (Thailand: Phuket); Wang and Liu 2003: 128, figs 171-172 (W Taiwan); Naiyanetr 2007: 112 (list: Gulf of Thailand); Dev Roy 2008: 135 (list; India); Huang 2008: 668 (list; China); Ng et al. 2008: 226 (list); Yang et al. 2008: 803 (list; East and South China seas); Rath and Dev Roy 2008: 72, pl. 4(5) (NE India); Liu and Wang 2010: 72, 3 unnumbered figs (W Taiwan); Lee et al. 2013: 108, 2 unnumbered figs (Taiwan: Tainan); Ng et al. 2017: 110 (list; Taiwan).

Materials examined. Taiwan: $8 \lesssim \widehat{\jmath}(6.1-14.0 \mathrm{~mm}), 4 q q(8.0-13.2 \mathrm{~mm})$ (NCHUZOOL 15479), Danshuei River mangroves, New Taipei City, coll. P.-Y. Hsu and J.-W. Hsu, 24 Mar. 2017; 4 ठึ̄ (11.8-15.9 mm), 4 우 (14.1-15.3 mm) (NCHUZOOL 15480), Jhuwei, New Taipei City, 4 Oct. 1995; 1 § (12.1 mm) (NCHUZOOL

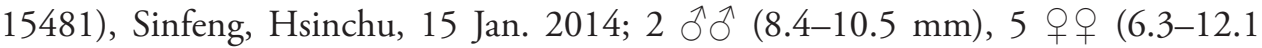
$\mathrm{mm}$ ) (NCHUZOOL 15482), Siangshan, Hsinchu, 11 Aug. 2008; 1 ภे (13.2 mm), 5 우우 (8.7-9.7 mm) (NCHUZOOL 15483), Siangshan, Hsinchu, 13 Mar. 2008; 4 ठึग (10.1-11.3 mm), 1 † (11.7 mm) (NCHUZOOL 15484), Haishangu, Hsinchu, 27 Aug. 2013; 1 ઈે (10.8 mm), 3 우 (8.8-11.6 mm) (NCHUZOOL 15485), Wufu Bridge, Miaoli, 2 Dec. 2015; 4 ổ (12.0-15.1 mm) (NCHUZOOL 15486),

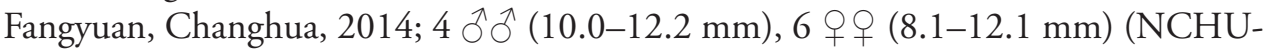
ZOOL 15487), Yuliao R. estuary, Changhua, coll. J.-W. Hsu et al., 16 Jan. 2017; 4 ổ (5.3-10.6 mm), 3 우우 (10.2-12.9 mm) (NCHUZOOL 15488), area between Yunlin and Chiayi, coll. K.-C. Li and C.-T. Wang, 25 Aug. 2003; 1 ते (12.7 mm) (NCHUZOOL 15496), Dongshih, Chiayi County, coll. P.-Y. Hsu, 24 Jan. 2017; 4

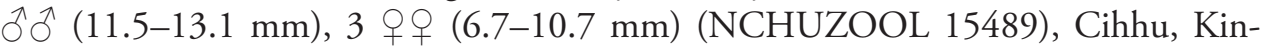
men, coll. H.-T. Shih and P.-Y. Hsu, 29 June 2018. China: 3 oq (14.0-16.8 mm) (NCHUZOOL 15495), Dongzhai Harbor, Hainan, 23 June 2004; 3 q (13.9-16.6 $\mathrm{mm}$ ) (NCHUZOOL 15457), Dongzhai Harbor, Hainan, 23 June 2004. Vietnam:

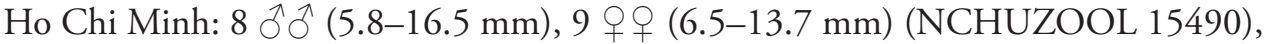
Rung Sac, Long Hoa, 12 Oct. 2017; 1 ते (18.2 mm), 1 q (12.7 mm) (NCHUZOOL 15491), TT. Can Thanh mangroves, Can Gio, 13 Oct. 2017; 5 ठ઼ (16.0-17.6 mm) (NCHUZOOL 15499), TT. Can Thanh mangroves, Can Gio, 13 Oct. 2017. Malaysia: 7 ठึ (7.7-12.6 mm), 14 q ○ (8.9-12.0 mm) (NCHUZOOL 15492), Mersing, Johor, 19 July 2010. Singapore: 1 specimen (not examined, only for DNA study; ZRC 1997.683), Sungei Buloh, 1996; 2 ऊิ 15493), Lim Chu Kang, 4 Mar. 2012. Thailand: 1 q (10.71 mm) (NCHUZOOL 15494), Ranong mangroves, 27 May 2012.

Diagnosis. Carapace (Figs 2A, 3A, F) trapezoidal, 1.45 times as broad as long $(N=127, \mathrm{SD}=0.06)$, longitudinally convex, broadest between lateral teeth 2 (exorbital angle included), surface sparsely but regularly furnished with short, stiff setae; front broad, divided into two broad lobes, medially concave; lateral margins markedly converging posteriorly, interrupted by four notches, delineating five teeth (including exorbital angle), exorbital angle most distinct, posterior two indistinct; posterolateral facet faintly defined, decorated by two oblique granular ridges. Infraorbital ridge 


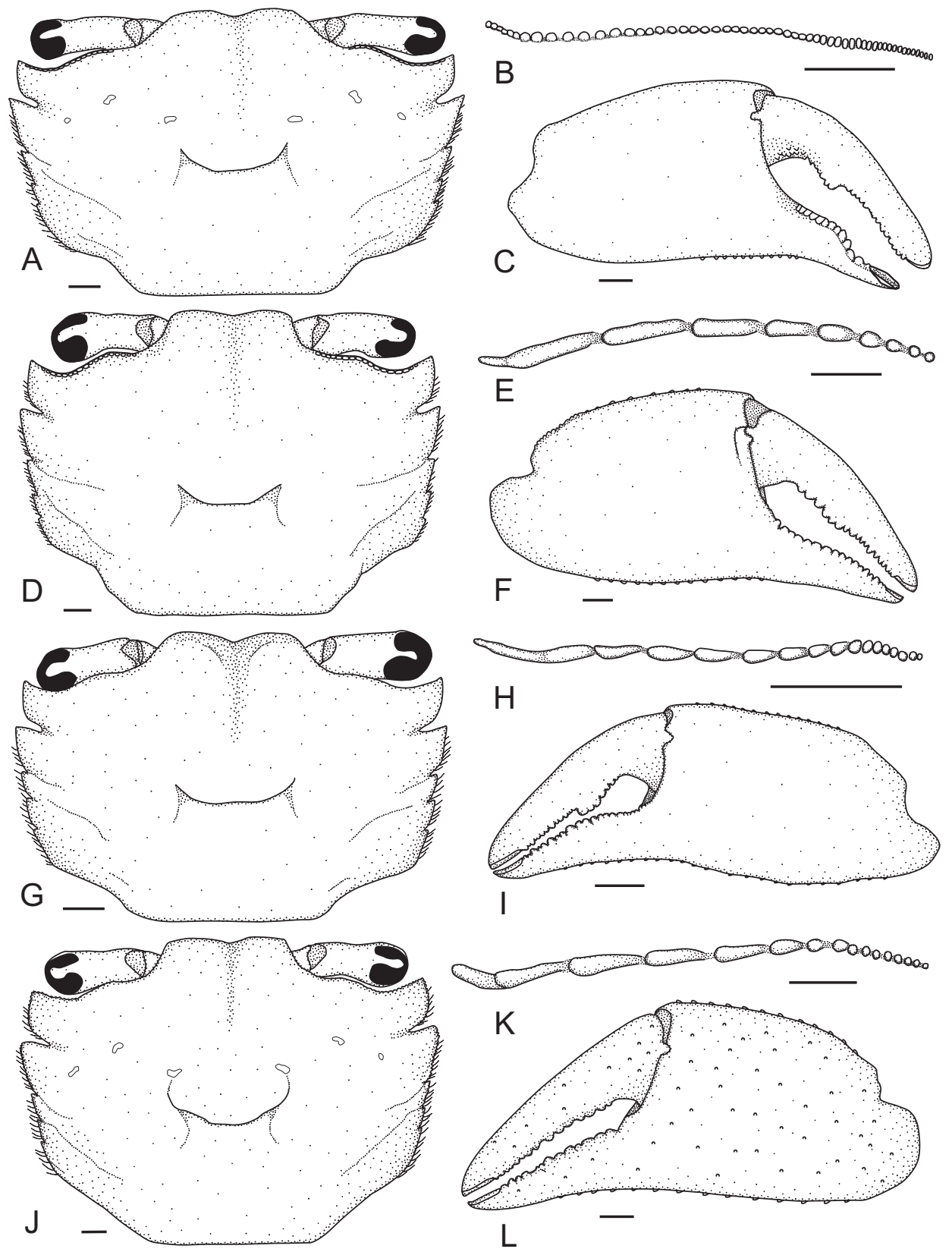

Figure 2. Metaplax elegans De Man, 1888 (A-C NCHUZOOL 15496, male, $12.7 \mathrm{~mm}$ ), M. longipes Stimpson, 1858 (D-F ZRC 2019.0581, male, 14.9 mm), M. sheni Gordon, 1930 (G-I NCHUZOOL 15466, male, $9.9 \mathrm{~mm}$ ), and $M$. tredecim Tweedie, 1950 (J-L paratype, ZRC 1964.7.14.4-18, 16.2 mm). A, $\mathbf{D , ~ G , J , A ~ c a r a p a c e ~ B , ~ E , ~ H , ~ K ~ l e f t ~ i n f r a o r b i t a l ~ r i d g e ~} \mathbf{C}, \mathbf{F}, \mathbf{I}, \mathbf{L}$ outer view of right cheliped. Scale bars: $1.0 \mathrm{~mm}$.

(Figs 2B, 3C) distinctly sexual dimorphic, males with 47-61 tubercles, medial seven closely set, almost fusing, lateral ca. 20 tubercles slightly vertically elongated; females with 33-42 isomorphic tubercles. Chelipeds (Figs 2C, 3D) symmetrical, in males more 


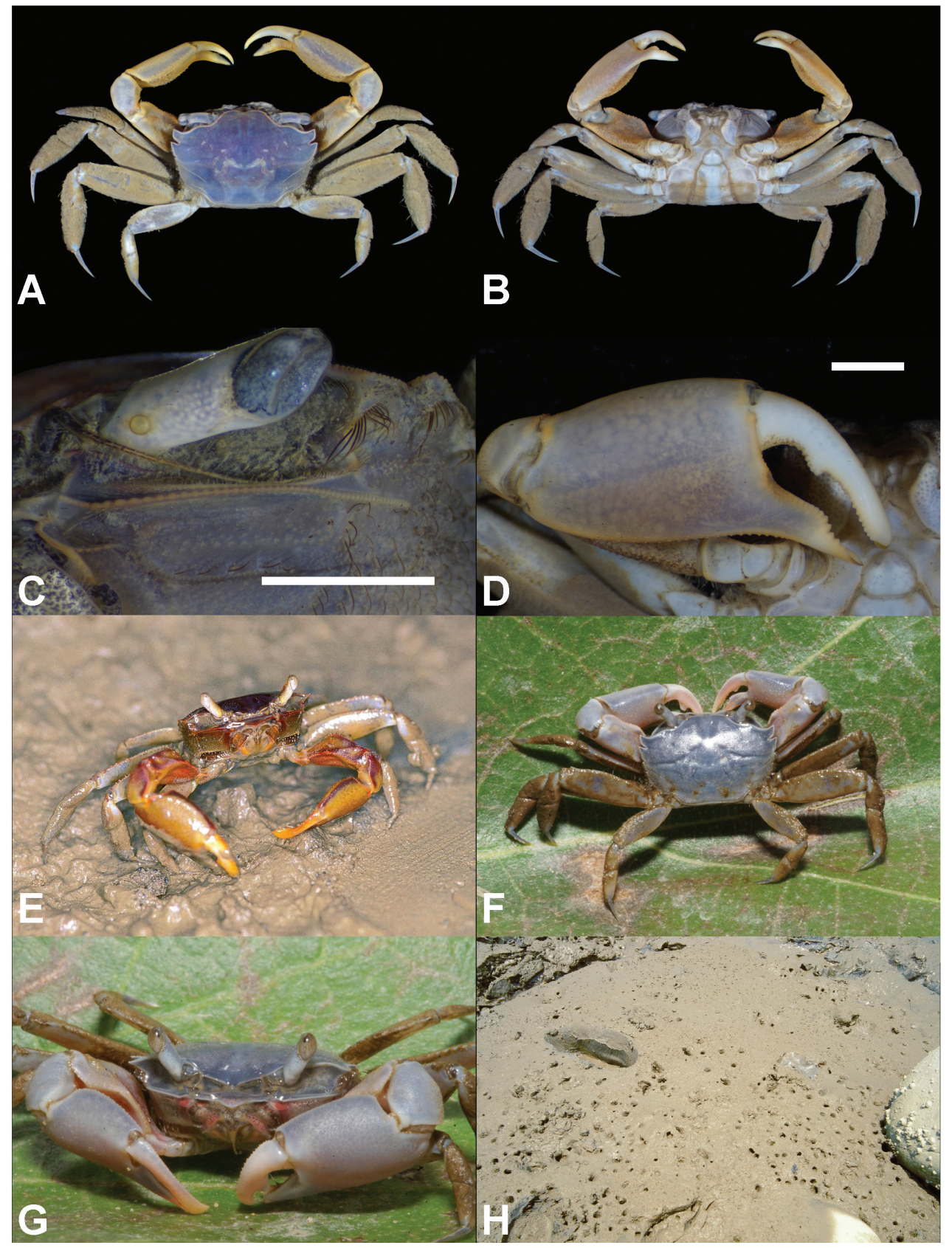

Figure 3. Metaplax elegans De Man, 1888. A Dorsal view B ventral view C left infraorbital ridge D right cheliped A-D male (CW 12.7 mm; NCHUZOOL 15496; Dongshih, Chiayi County, Taiwan) $\mathbf{E}, \mathbf{F}$ live coloration $\mathbf{E}$ photo taken in Gaomei, Taichung, Taiwan (specimen not collected) F-G male (CW $13.1 \mathrm{~mm}$; NCHUZOOL 15489; Kinmen, Taiwan) $\mathbf{G}$ the typical habitat (Gaomei, Taichung, Taiwan). Scale bars: $2.0 \mathrm{~mm}$. 
Table 2. Comparison of characters among four species of Metaplax from East Asia and northern Vietnam.

\begin{tabular}{|c|c|c|c|c|}
\hline Characters & M. elegans & M. longipes & M. sheni & M. tredecim \\
\hline lateral margin & five teeth & five teeth & five teeth & five teeth \\
\hline infraorbital ridge & $\begin{array}{l}\text { 46-61 tubercles in } \\
\text { males (lateral } 20 \\
\text { vertically elongated); } \\
33-42 \text { isomorphic } \\
\text { tubercles in females }\end{array}$ & $\begin{array}{l}7-13 \text { tubercles in } \\
\text { males (mesial ones } \\
\text { broad, and gradually } \\
\text { decreasing in size); } \\
14-22 \text { isomorphic } \\
\text { tubercles in females }\end{array}$ & $\begin{array}{l}\text { 16-20 tubercles in } \\
\text { males (mesial ones } \\
\text { broad, decreasing in } \\
\text { size laterally; mesial- } \\
\text { most one more than } \\
\text { twice the breadth of } \\
\text { the next) }\end{array}$ & $\begin{array}{l}13-20 \text { tubercles in } \\
\text { males (mesial ones broad } \\
\text { and decreasing in size, } \\
\text { lateral } 4-5 \text { roughly same } \\
\text { size); } 20-27 \text { isomorphic } \\
\text { tubercles in females }\end{array}$ \\
\hline cheliped & $\begin{array}{l}\text { palm } 2.2 \text { times as long } \\
\text { as broad, total length } \\
\text { of palm nearly } 1.8 \\
\text { times than length of } \\
\text { dactyl, cutting edge of } \\
\text { dactylus with distinct } \\
\text { large teeth }\end{array}$ & $\begin{array}{l}\text { palm } 2.3 \text { times as } \\
\text { long as broad, length } \\
\text { of palm nearly } 1.3 \\
\text { times than length of } \\
\text { dactyl, cutting edge } \\
\text { of dactylus with low } \\
\text { triangular molar, } \\
\text { pollex unarmed }\end{array}$ & $\begin{array}{l}\text { markedly elongated, } \\
\text { palm } 2.8 \text { times as long } \\
\text { as broad, length of } \\
\text { palm nearly } 2.0 \text { times } \\
\text { than length of dactylus, } \\
\text { cutting edge of dactylus } \\
\text { with triangular molar }\end{array}$ & $\begin{array}{c}\text { palm } 2.3 \text { times as long } \\
\text { as broad, length of palm } \\
\text { nearly } 1.6 \text { times than } \\
\text { length of dactyl, cutting } \\
\text { edge of both fingers } \\
\text { unarmed }\end{array}$ \\
\hline ambulatory legs & short, broad & long, slender & long, slender & long, slender \\
\hline
\end{tabular}

elongated and robust, palm 2.2 times as long as broad, length of palm approximately 1.8 times longer than dactyl $(N=20)$, pollex of chela with low sinuous tooth along cutting margin, dactylus with distinct triangular molar. Ambulatory legs elongated, meri broad, merus of P4 distally armed with several short spines on anterior margin; anterior margins of all ambulatory legs fringed with setal patches. G1 (Fig. 7A-D) long, slender, distal process triangular, distinctly curved outward.

Distribution. The Bay of Bengal, Southeast and East Asia: China (Zhejiang; Fujian; Guangdong; Hainan), western Taiwan (including Kinmen), Vietnam, Malaysia (Selangor; Sarawak; Labuan), Singapore, Brunei, Thailand, Myanmar (Mergui), and eastern India (Tamil Nadu, Godavari Delta) (Fig. 1).

Habitat. At Wazihwei Wetland, estuaries of Danshuei River, northwestern Taiwan, this species is found along shores with substantial freshwater influence, on banks with substrates plastic-muddy, somewhat distant from mangrove stands.

Remarks. According to previous descriptions (De Man 1888, Dai et al. 1986, Dai and Yang 1991), the infraorbital ridges of $M$. elegans bear 50-60 tubercles in males and 35-40 tubercles in females. In the present study of 21 males and 19 females, CW ranging from 7.7 to $15.9 \mathrm{~mm}$, and the range of variation is slightly wider than previously reported, being 47-61 in males and 33-42 isomorphic tubercles in females (Table 2, Fig. 8).

\section{Metaplax longipes Stimpson, 1858}

Figures 2D-F, 4, 7E-H

Metaplax longipes Stimpson, 1858: 97 (type locality: Hong Kong); Koelbel 1897: 711, pl. 1(5-6) (Hong Kong); Stimpson 1907: 99 (Hong Kong); Tesch 1918: 116 (key; no new specimens); Gee 1926: 164 (China: "Chin Bey"); Gordon 1931: 528 (Hong Kong; China: Amoy (= Xiamen), Fujian); Shen 1940a: 74, 95 (China: Zhejiang; 
Fujian); Shen 1940b: 236 (Hong Kong); Shen and Dai 1964: 133, 1 unnumbered fig. (China: Zhejiang; Fujian; Guangdong); Dai et al. 1986: 508, fig. 288 (1-2), pl. 72(3) (China: Zhejiang; Fujian; Guangdong) (part); Chen 1991: 441, fig. 416; Dai and Yang 1991: 556, fig. 288 (1-2), pl. 72(3) (China: Zhejiang; Fujian; Guangdong) (part); Davie 1992: 352 (key); Huang 1994: 598 (list; China); Wang and Liu 1996c: 227 (list); Lee 2001: 115, 3 unnumbered figs (W Taiwan); Ng et al. 2001: 54 (list; Taiwan); Davie and Nguyen 2003: 384 (no specimen examined); Wang 2003: 111, 1 unnumbered fig. (Taiwan: Kinmen); Liu and He 2007: 167: 1 unnumbered fig. (China: Yangtze R. estuary); So and Lui 2007: 36, 3 unnumbered figs (Hong Kong); Huang 2008: 668 (list; China); Ng et al. 2008: 226 (list); Yang et al. 2008: 803 (list; East and South China seas); Ng et al. 2017: 110 (list; Taiwan). Metaplax takahasii Sakai, 1939: 698, text-fig. 127 (type locality: Tansui (= Danshuei), Taiwan); Sakai 1940: 58 (list; Japan; Taiwan); Lin 1949: 31 (list; Taiwan); Fukui et al. 1989: 230, fig. 24 (Taiwan: New Taipei City); Dai and Yang 1991: 556, fig. 288 (3-4), pl. 72(4) (China: Fujian; Guangdong); J.-T. Shih et al. 1991: 126 (Taiwan: New Taipei City); Davie 1992: 352, pl. 2A (Hong Kong); Lee and Leung 1999: 69 (Hong Kong).

Metaplax takahashii: Horikawa 1940: 30 (list; Taiwan); Sakai 1976: 673, text-fig. 371 (Taiwan: Danshuei); Dai et al. 1986: 508, fig. 288 (3-4), pl. 72(4) (China: Fujian; Guangdong); Huang 1994: 598 (list; China); Kosuge et al. 1997: 182 (Vietnam: Haiphong); Muraoka 1998: 54 (Danshuei R., Taiwan); Ng et al. 2001: 46 (list; Taiwan); Kitaura et al. 2002: 684 (Vietnam: Haiphong); Davie and Nguyen 2003: 384 (no new specimens); Ng et al. 2017: 110 (list; Taiwan); Huang 2008: 668 (list; China); Ng et al. 2008: 226 (list; Taiwan).

? Metaplax longipes: Naiyanetr 2007: 112 (list: Gulf of Thailand).

Not Metaplax longipes: Davie 1992: 352 (key) (= Metaplax tredecim Tweedie, 1950).

Not Metaplax longipes: Chertoprud et al. 2012: 276, pl. 47F (Nha Phu, southeastern Vietnam) (= Metaplax tredecim Tweedie, 1950).

Materials examined. China: 2 ภึ (20.7-22.7 mm) (NCHUZOOL 15443), Sheyang, Jiangsu, coll. W.-R. Lin, 24 Aug. 2015; 3 ऊิ (11.3-22.3 mm), 1 ㅇ (21.6 mm) (NCHUZOOL 15444), Mamu, Zhoushan, Zhejiang, 26 July 2018; 6 ふ઼ (15.9$26.6 \mathrm{~mm}), 3$ 우우 (18.0-19.15 mm) (NCHUZOOL 15446), Mamu, Zhoushan, Zhejiang, Sep. 2018; 2 ふึ (13.9-15.6 mm), 5 우 (13.6-23.6) (NCHUZOOL 15447), Mamu, Zhoushan, Zhejiang, 26 July 2018; 1 q (16.8 mm) (NCHUZOOL 15445), Buqiangwan, Zhoushan, Zhejiang, 26 July 2018; 2 ઈิ (12.0-12.1 mm), 4 q 9 (9.8$18.6 \mathrm{~mm}$ ) (NCHUZOOL 15448), Liuwudian, Xiamen, Fujian, 31 July 2018; 1 त (19.2 mm) (NCHUZOOL 15449), Qinzhou, Guangxi, 10 May 2009. Hong Kong: 1 đ (18.3 mm) (NCHUZOOL 15451), Tung Chung, coll. K. J. H. Wong, 21 Mar.

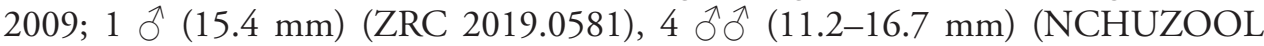
15450), Tung Chung, coll. K. J. H. Wong, 9 Apr. 2016; 1 đ (9.3 mm), 2 q $9.8 \mathrm{~mm}$ ) (NCHUZOOL 15452), Tung Chung, coll. K. J. H. Wong, 11 July 2015;

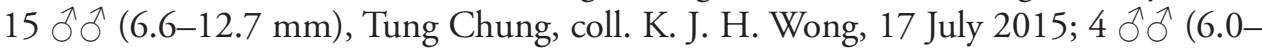




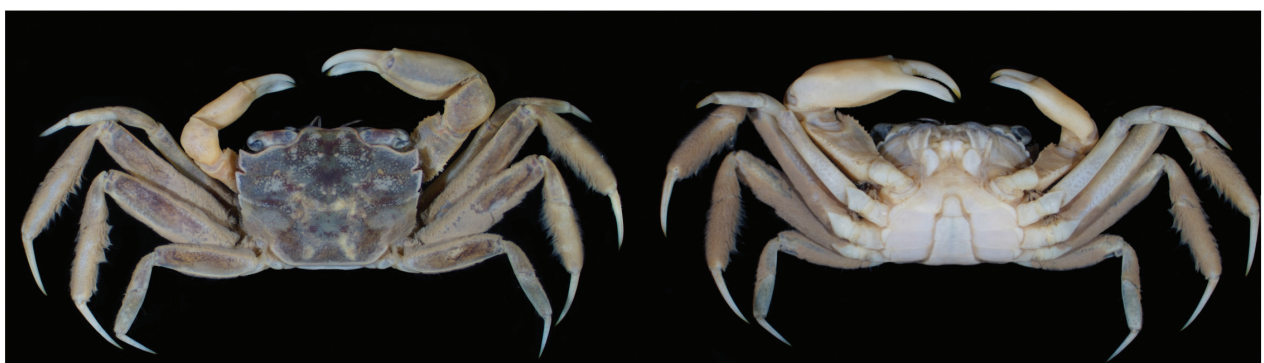

A

B

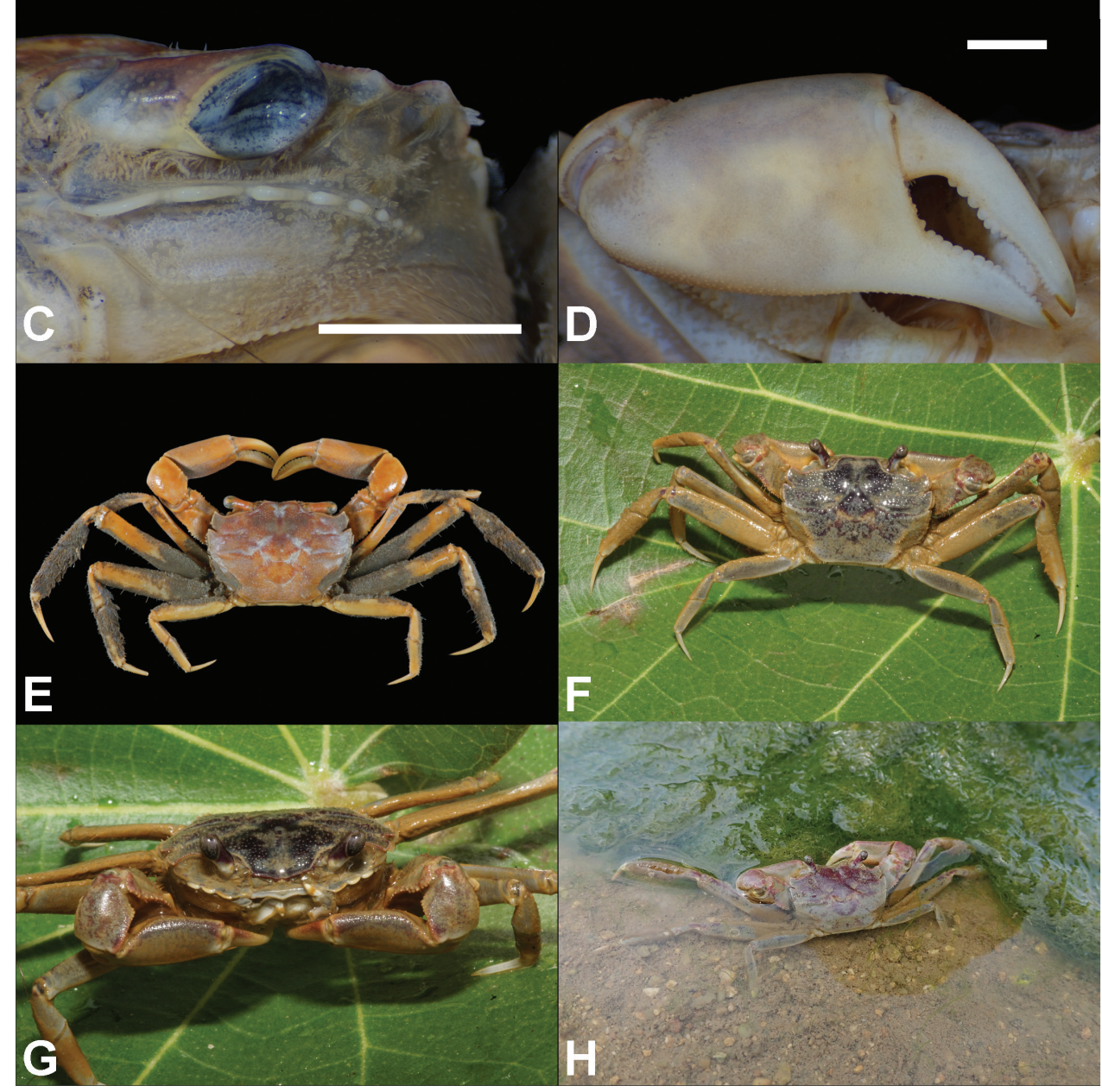

Figure 4. Metaplax longipes Stimpson, 1858. A, E Dorsal view B ventral view C left infraorbital ridge D right cheliped. A-D Male (CW 15.4 mm; ZRC 2019.0581; Hong Kong) E male (CW 24.1; ZRC 1999.0708; Danshuei, northwestern Taiwan) F-H live coloration F-G male (CW $20.6 \mathrm{~mm}$; NCHUZOOL 15553; Lieyu, Kinmen, Taiwan) H male (CW 23.7 mm; NCHUZOOL 15501; Hong Kong). Scale bars: $2.0 \mathrm{~mm}$. 
$8.8 \mathrm{~mm}$ ) (NCHUZOOL 15455), Tung Chung, coll. K. J. H. Wong, 18 July 2011; 3

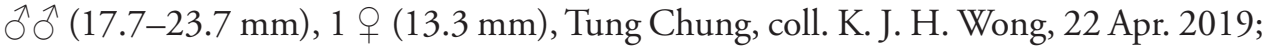
3 ठิ $\widehat{o}(6.8-8.6 \mathrm{~mm}), 3$ 우 $(10.0-14.7 \mathrm{~mm})$ (NCHUZOOL 15503), Tung Chung, coll. H.-T. Shih and K. J. H. Wong, 2 June 2019; 1 ऽ (17.6 mm) (NCHUZOOL

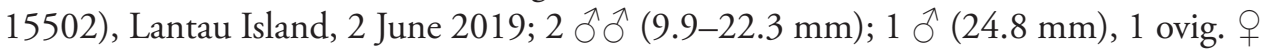
$(19.0 \mathrm{~mm})$ (ZRC 2019.0542), ca. 22.495486N, 114.029947E, mudflats at mangroves, Mai Po Nature Reserve, coll. K. J. H. Wong, 24 May 2019. Macao: 1 ( $(17.5 \mathrm{~mm})$ (NCHUZOOL 15454), Coloane, coll. K. J. H. Wong, 3 July 2015. Taiwan: 1 q (17.7 mm) (KPM-NH 0107076), Danshuei, New Taipei City, coll. S. Takahashi (?), 1933 (?); 1 $(14.7 \mathrm{~mm})$ (NTOU), Danshuei, New Taipei City, 25 May 1984; 1 q (14.4 mm) (NTOU), Danshuei, New Taipei City, coll. L.-H. Hsieh, 7 May 1992; 2 ðठ (10.6-20.0 mm) (ASIZ), Danshuei River mangroves, New Taipei City, 17 Mar. 1986; 1 đ̊ (24.1 mm) (ZRC 1999.0708), Danshuei, New Taipei City, 8 July 1999; 1 ô (21.8

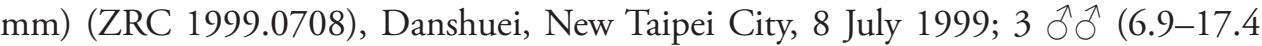
$\mathrm{mm}), 2$ 우 $(7.9-10.3 \mathrm{~mm}$ ) (NCHUZOOL 15458), Wujiang R. estuary, Kinmen, 6 Mar. 2008; 1 ภ (19.1 mm), 1 क (16.9 mm) (NCHUZOOL 15459), Wujiang R.

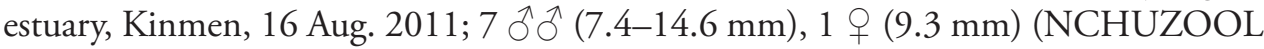
15460), Wujiang R. estuary, Kinmen, coll. H.-T. Shih and P.-Y. Hsu, 29 June 2018;

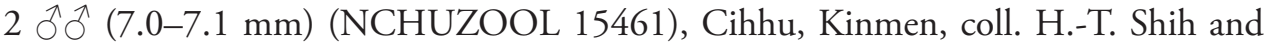
P.-Y. Hsu, 29 June 2018; 1 ( (19.9 mm) (NCHUZOOL 15462), Mashan, Kinmen, 17 Aug. 2011; 1 ㅇ (21.1 mm) (NCHUZOOL 1551), 1 q $(5.9 \mathrm{~mm})$ (NCHUZOOL 15552), 1 đ (20.6 mm), 1 ㅇ (17.5 mm) (NCHUZOOL 15553), 1 q (20.1 mm) (NCHUZOOL 15554), Lieyu, Kinmen, coll. H.-T. Shih and P.-Y. Hsu, 28 June, 2018; 1 ऊิ (18.1 mm) (NCHUZOOL 15463), Cingshuei, Matsu, coll. J.-H. Li, 9 July 2005; 1 đ (20.0 mm) (NCHUZOOL 15464), Cingshuei, Matsu, coll. J.-H. Li, 9 July 2005.

Diagnosis. Carapace (Figs 2D, 4A, E, F) subquadrate, 1.36 times broader than long $(N=98, \mathrm{SD}=0.05)$, mildly convex longitudinally and laterally, region faintly defined; front medially slightly concave; lateral margin nearly parallel, interrupted by four notches (cutting into five teeth), anterior two lateral teeth pronounced, posterior two very indistinct; posterior facet depressed, decorated by two oblique granular ridges, anterior one extended from second notch. Infraorbital ridge (Figs 2E, 4C) marked sexually dimorphic: males with 7-13 lobes and tubercles, medial 2 broad, decreasing in breadth laterally, innermost four or five decreasing in size, lateral ones small, isomorphic; females with 16-22 small isomorphic tubercles. Chelipeds (Figs 2F, 4D) symmetrical, robust, palm 2.3 times as long as broad, length of palm approximately 1.3 times length of dactyl $(N=16)$, merus denticulate along anterior and posterior margins; chelae surface smooth, pollex and dactylus unarmed of pronounced molars along cutting edge. Ambulatory legs slender, elongated, meri unarmed along anterior margin, proximal half of meri, and propodi of all furnished with setal mats. G1 (Fig. 7E-H) elongated, relatively stout, almost straight.

Distribution. Western Taiwan (including Matsu and Kinmen), China (Jiangsu; Zhejiang; Fujian; Guangdong; Guangxi), and northern Vietnam (Haiphong) (Fig. 1). The record in the Gulf of Thailand (Naiyanetr 2007: 112) requires further verification. 
Habitat. At Tung Chung Wetland, Hong Kong, where numerous specimens were collected, the habitat of this species is composed of muddy substrates and substantial freshwater influences. Considerable numbers flourish under fringes of mangrove stands, as well as the adjacent more open mudflats.

Remarks. The identity of Metaplax longipes had long remained unclear since the publication of M. takahasii Sakai, 1939. The confusion between the two nominal species was mainly caused by two crucial morphological features used for species identification: the number of tubercles and lobes along the male infraorbital ridge, and the number of teeth on the lateral margin of the carapace.

Originally described from Hong Kong by Stimpson $(1858,1907)$, type material(s) of M. longipes was destroyed in the Great Chicago Fire in 1871 (Evans 1967). Illustrations based on material from Hong Kong were eventually presented by Koelbel (1897: pl. 1(5-6)), and further records from Hong Kong and elsewhere in South China include those by Gee (1926), Gordon (1931), Shen (1940a, b) and Shen and Dai (1964). Morphology of the infraorbital ridge in males serves as a good taxonomic character (Tesch 1918); delimitations provided in various work under the name M. longipes range from 7 to 10: "seven-lobed" (Stimpson 1907), "fogak száma összesen tehát kilencz" (= total number of nine teeth; Koelbel 1897), "number of lobules or teeth ... 7-9" (Tesch 1918, Gordon 1931), and "9 to 10 tubercles" (Shen and Dai 1964).

Interpretations of M. longipes by Dai et al. (1986) and Dai and Yang (1991) brought much confusion. These authors illustrated two forms of infraorbital ridges based on specimens from South China (Guangdong to Zhejiang), one bearing 17 lobes and tubercles, and the other bearing nine (fig. 288(1) in Dai et al. 1986 and Dai and Yang 1991). It appeared very likely that their material was composite (also see Remarks under $M$. tredecim). Anyhow, this "shift" in the number of tubercles was subsequently followed by various authors: "with 15-17 lobules and teeth" (Davie 1992) and "about 9-17 tubercles" (Lee and Leung 1999). Reflecting this confused situation, the dichotomous key to the Metaplax species provided by Davie (1992: 352), which differentiated "M. longipes" (15 to 17 lobules and teeth) from "M. takahasii" (9 teeth), was problematic. Following diagnoses given by Stimpson $(1858,1907)$, and authors such as Gordon (1931) and Shen and Dai (1964), only those with around 9 lobes or tubercles, should be considered as the true M. longipes.

Without accessing any material of $M$. longipes from South China, Sakai (1939) described a similar form named $M$. takahasii based on one male specimen from Tansui (= Danshuei), northwestern Taiwan, after the naturalist and collector, Sadae Takahashi (or Sadae Takahasi in another translation). The species was subsequently reported elsewhere in China, including Guangdong and Fujian (Dai et al. 1986; Dai and Yang 1991) and Hong Kong (Davie 1992). Regarding the correct spelling of the species epithet, "takahasii" (original as in Sakai 1939), instead of "takahashii" as in Sakai (1976), should be maintained (ICZN 1999: Article 32.2).

Nevertheless, $M$. takahasii was described with an infraorbital ridge composed of 8 tubercles and the lateral margin of the carapace cut into five teeth. Considering the original descriptions of M. longipes and M. takahasii (Stimpson 1907 and Sakai 1939, 
respectively), holotypes of the two (CW $15.5 \mathrm{~mm}$ and $14.2 \mathrm{~mm}$, respectively) differ by the numbers of lateral carapace teeth (four vs. five) of the carapace and the infraorbital lobes and tubercles (seven vs. eight). The number of infraorbital tubercles of both forms overlap might be explained by variation between intraspecific individuals (see "Note on the number of infraorbital tubercles and lobes"; Fig. 8), whereas the posterior-most notch along the lateral margin, however, can be very indistinct and often obscured by a layer of sediment-laden setae and easily omitted (Davie and Nguyen 2003; see Remarks under $M$. tredecim below). This led Davie and Nguyen (2003:384) to the view that $M$. longipes is "almost certain(ly) ... a senior synonym of $M$. takahashii". In enumerating Chinese species of Metaplax, Yang et al. (2008: 803), probably following Davie and Nguyen's (2003) suggestion, listed $M$. takahasii as a junior synonym of $M$. longipes without further elaboration. In our material referred to $M$. longipes, the number of infraorbital tubercles and lobes varies from 7-13 for males and 14-22 in females (Table 2; Fig. 8)

In the present study, we compared specimens from Hong Kong (identified as $M$. longipes) and various lots from Taiwan main island (originally labeled as M. takahasii: see Materials examined above) with morphological and molecular approaches. As noted by Davie and Nguyen (2003; also see above), the number of notches (hence teeth) on the lateral margin of the carapace is easily underestimated unless the surface is carefully denuded. This aspect is well-illustrated in the case of $M$. tredecim (as discussed below), and also between specimens of $M$. longipes from Hong Kong (Fig. 4A) and "M. takahasii" from Danshuei, Taiwan (Fig. 4E), the two being identical. Molecular analyses also support only one clade of specimens from various localities of China and Taiwan (Table 1; Fig. 9).

\section{Metaplax sheni Gordon, 1930}

Figures 2G-I, 5, 7I-L

Metaplax sheni Gordon, 1930: 525 (type locality: Amoy (= Xiamen), Fujian, China); Gordon 1931: 553, figs 31-32 (China: Xiamen, Fujian); Tweedie 1936: 69, fig. 15(5) (Singapore); Shen 1940a: 74, 95 (China: Zhejiang; Fujian); Shen and Dai 1964: 133, 1 unnumbered fig. (China: Fujian); Dai et al. 1986: 509, fig. 289 (3-4), pl. 72 (6) (China: Fujian); Chen 1991: 441, fig. 415 (China: Zhejiang); Dai and Yang 1991: 558, fig. 289 (3-4), pl. 72(6) (China: Fujian); Huang 1994: 598 (list; China); Tan and Ng 1994: 82 (Singapore); Kosuge et al. 1997: 182 (Vietnam: Haiphong); Kitaura et al. 2002: 684 (Vietnam: Haiphong); Davie and Nguyen 2003: 383 (Malaysia: Johor; Singapore); Huang 2008: 668 (list; China); Ng et al. 2008: 226 (list); Yang et al. 2008: 803 (list; China: Fujian).

Metaplax indica: Rathbun 1931: 100 (China: Fujian); Shen 1940a: 74, 95 (list; South China). (not M. indica H. Milne Edwards, 1852)

Materials examined. China: 5 $\widehat{\partial}(8.6-12.8 \mathrm{~mm})$ (NCHUZOOL 15465), Wuyuanwan, Xiamen, Fujian, coll. H.-T. Shih et al., 1 Aug. 2018. Taiwan: 1 ภ $(9.9 \mathrm{~mm})$ 


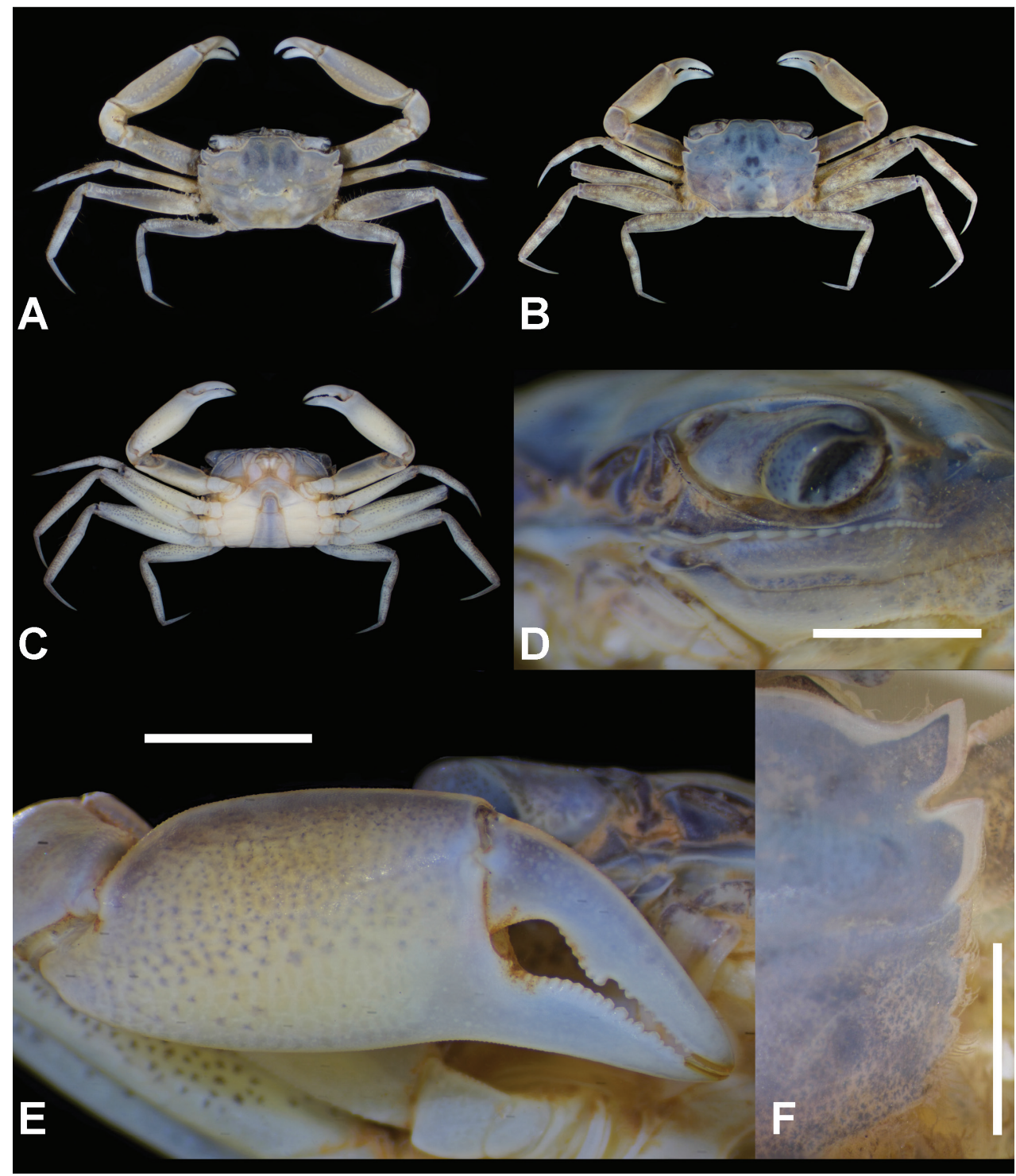

Figure 5. Metaplax sheni Gordon, 1930. A, B dorsal view $\mathbf{C}$ ventral view D left infraorbital ridge $\mathbf{E}$ right cheliped $\mathbf{F}$ right side of carapace showing the five teeth of lateral margin. A, C Male (CW $12.8 \mathrm{~mm}$; NCHUZOOL 15465; Xiamen, Fujian, China) B, D-F male (CW 9.9 mm; NCHUZOOL 15466; Dong Rui, Quang Ninh, Vietnam). Scale bars: $2.0 \mathrm{~mm}$.

(NCHUZOOL 15467), Kinmen. Vietnam: 1 ऽ (9.9 mm) (NCHUZOOL 15466), Dong Rui, Quang Ninh, coll. H.-T. Shih et al., 29 May 2016.

Diagnosis. Carapace (Figs 2G, 5A, B) subquadrate, 1.45 times broader than long $(N=7, \mathrm{SD}=0.04)$, longitudinally convex, regions faintly defined; frontal margin sinuous, medially noticeably concave; lateral margin markedly converging posteriorly, furnished with a row of soft setae, interrupted by four notches, cutting into five teeth, 
anterior two marked, triangular, last two weak, indistinct. Infraorbital ridge (Figs $2 \mathrm{H}$, 5D) of males with 16-20 lobes and tubercles, innermost tubercle more than twice as broad as the adjacent, followed by six broad tubercles, decreasing in size. Chelipeds (Figs 2I, 5E) of males subequal, markedly elongated, palm 2.8 times as long as broad, length of palm approximately 2 times longer than length of dactyl $(N=6)$, merus and palm subequal in length; both fingers about half-length of palm, deflexed; cutting edges of pollex with low, serrated lobe, dactylus bearing distinct triangular molar. Ambulatory legs slender, elongated, anterior margins of meri finely serrated; anterior margins of carpi and propodi line with thick tomentum. G1 (Fig. 7I-L) elongated, relatively stout almost straight.

Distribution. China (Zhejiang, Fujian), Taiwan (Kinmen), Vietnam (Khanh Hoa; Haiphong; Quang Ninh), and Malay Peninsula (including Singapore) (Fig. 1).

Remarks. One curious record of $M$. indica was reported by Rathbun (1931) from Tsimei, Amoy (= Jimei, Xiamen), along the coasts of Fujian. Other than this record, there have been no definite records of $M$. indica from China, despite that of Shen (1940a) citing that of Rathbun's (1931). Given the considerable resemblance between M. indica (see Naderloo 2011: figs 15, 18c-d; Naderloo 2017: figs 31.11e, 32.2, 32.3) and M. sheni, and the latter described from the region (Amoy) shortly before, it is reasonable to consider Rathbun's (1931) record represented M. sheni.

Specimens collected from Kinmen, opposite Xiamen (Fujian, China), are confirmed as $M$. sheni based on molecular analyses (see below), being a new record to Taiwan.

\section{Metaplax tredecim Tweedie, 1950}

Figures 2J-L, 6, 7M-P

Metaplax tredecim Tweedie, 1950: 354, fig. 6 (type locality: Labuan, Malaysia); Choy and Booth 1994: 243 (Brunei); Davie and Nguyen 2003: 383, fig. 1d-e (Malaysia: Labuan; Brunei); Ng et al. 2008: 226 (list); Yang et al. 2008: 803 (list; East China and South China seas).

Metaplax longipes: Dai et al. 1986: 508, fig. 288 (1-2), pl. 72(3) (China: Zhejiang, Fujian, Guangdong) (part); Dai and Yang 1991: 556, fig. 288 (1-2), pl. 72(3) (China: Zhejiang, Fujian, Guangdong) (part); Chertoprud et al. 2012: 276, pl. 47F (Vietnam: Nha Phu, Nha Trang, Khanh Hoa) (not M. longipes Stimpson, 1858).

Materials examined. Paratypes: $2 \hat{\jmath}(15.6-16.2 \mathrm{~mm}), 1 \stackrel{1}{ }$ (15.7 mm) (ZRC 1964.7.14.4-18), Labuan, Malaysia, coll. G. Nunong, Aug. 1938. Others. Hong Kong: $1 \overbrace{}^{\Uparrow}(14.2 \mathrm{~mm})$ (NCHUZOOL 15468), Starfish Bay, coll. P.-C. Tsai and H. Y. Cheung, 19 July 2015; 3 ô ô (16.4-19.4 mm) (NCHUZOOL 15546), Starfish Bay, coll. K. J. H. Wong, 4 June 2019; 1 ô (16.1 mm) (NCHUZOOL 15469), Tai Tan, coll. K. J. H. Wong, 15 July 2015; 1 ○ (18.1 mm) (NCHUZOOL 15470), Ting

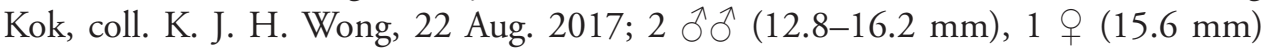

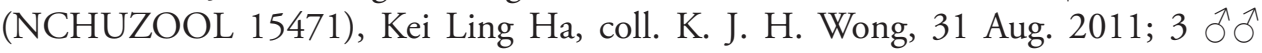




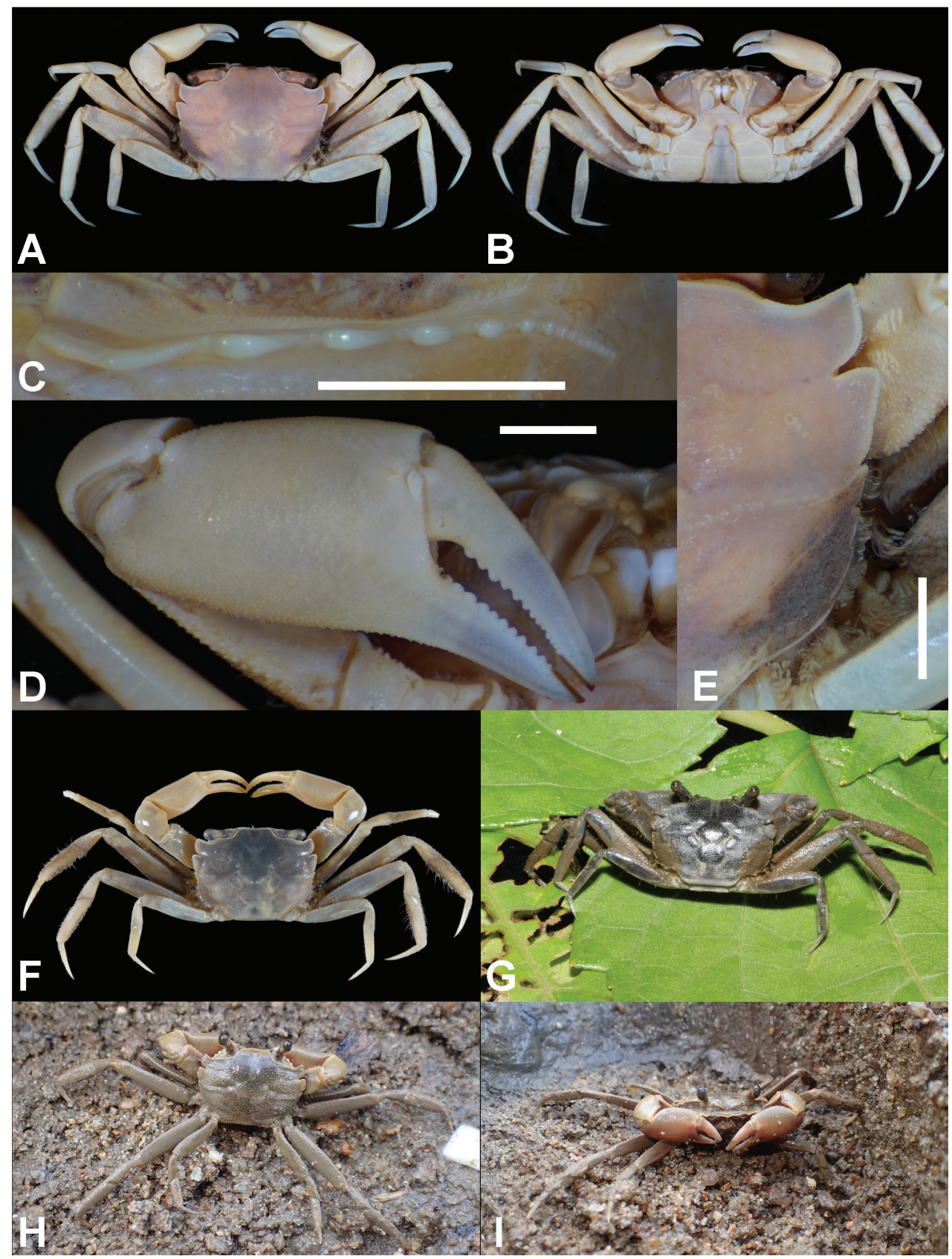

Figure 6. Metaplax tredecim Tweedie, 1950. A, F Dorsal view B ventral view C left infraorbital ridge $\mathbf{D}$ right cheliped $\mathbf{E}$ right side of carapace showing the five teeth of lateral margin. A-E paratype male $(C W$ 16.2 mm; ZRC 1964.7.14.4-18; Labuan) F male (CW 16.5 mm; NCHUZOOL 15473; Hong Kong) G male (CW 15.4 mm; NCHUZOOL 15475; Labuan, Malaysia) H, I male (18.2 mm; NCHUZOOL 15705; Hong Kong) G-I color in life. Scale bars: $2.0 \mathrm{~mm}$. 
(16.9-21.0 mm) (NCHUZOOL 15472), Nai Chung, coll. K. J. H. Wong, 23 June 2015; 2 ઊ઼ (16.5-21.5 mm) (NCHUZOOL 15473), Luk Keng, coll. C. W. Lau, 22 May 2016; 1 § (18.2 mm) (NCHUZOOL 15705), Mak Pin, Sai Kung, coll. K. J. H. Wong, 7 July 2019. China: 4 ठิ $\widehat{~}(18.0-22.7 \mathrm{~mm}), 1$ ( $10.7 \mathrm{~mm})$ (NCHUZOOL 15474), Dongzhai Harbor, Hainan, 23 June 2004. Vietnam: Quang Ninh: 1 o (21.8 $\mathrm{mm}), 2$ 우 (15.7-23.4 mm) (NCHUZOOL 15476), Dong Rui, 29 May 2016; 1 § (22.4 mm) (NCHUZOOL 15477), Dong Rui, coll. H.-T. Shih and P.-Y. Hsu, 9 Oct. 2017; 1 q (10.3 mm) (NCHUZOOL 15478), Dong Rui, coll. H.-T. Shih and P.-Y. Hsu, 9 Oct. 2017; Khanh Hoa: 4 ô ô (14.4-18.7 mm), 5 q $q$ (12.6-16.1 mm) (NCHUZOOL 15498), Nha Trang, coll. I.-H. Chen and K. J. H. Wong, 24 Nov. 2010. Malaysia: Labuan, 1 o (15.4 mm), 1 क (16.2 mm) (NCHUZOOL 15475), coll. H.-T. Shih, 23 July 2010; 1 ô (17.1 mm) (NCHUZOOL 15497), coll. H.-T. Shih, 27 July 2010.

Diagnosis. Carapace (Figs 2J, 6A, F, G) subquadrate, 1.35 times broader than long $(N=39, \mathrm{SD}=0.03)$, regions defined by shallow grooves, slightly inflated, surface pitted; front nearly straight, medially slightly concave; lateral margin mildly convex, posteriorly converging, cut into five teeth, anterior two pronounced, quadrate, posterior two inconspicuous; posterolateral facet slightly depressed, behind second notch decorated with two short oblique granular ridges. Infraorbital ridge (Figs 2K, 6C) markedly sexually dimorphic: in males medial four or five roughly same size, decreasing in breadth laterally, laterally of a row of seven or eight small, rounded, isomorphic, tubercles; females with 21-27 small isomorphic tubercles. Chelipeds (Figs 2L, 6D) stout, symmetrical, palm 2.3 times longer than broad, length of palm approximately 1.6 times of length of dactyl $(N=12)$, meri slightly dilated anteriorly, lined with minute denticles along the margin; chela surface finely granulated, along cutting edges both fingers unarmed. Ambulatory legs slender, elongated, meri of P3 and P4 tomentum-covered on distal half, and propodi of P2 to P4 with thick mat of setae. G1 (Fig. 7M-P) elongated, slender, almost straight.

Distribution. Southeast and East Asia: northern Borneo (Labuan, Malaysia; Brunei), Vietnam (Quang Ninh; Khanh Hoa), and South China (Hong Kong) (Fig. 1).

Habitat. In Hong Kong, in comparison to M. longipes, M. tredecim tends to occur in habitats of coarser, grittier substrates, with less freshwater input, and frequently on open sandflats rather unsheltered by mangroves.

Remarks. Identification of the Metaplax tredecim had been confusing, particularly based on the number of teeth along the lateral margin of the carapace. Tweedie (1950: fig. 6) showed merely three conspicuous lobes, the posterior one occupying more than half of carapace length. However, as noted by Davie and Nguyen (2003), members of the genus often have the structures around the posterolateral facet obscured by setae-trapped sediments, and not visible unless carefully denuded. Reexamination of a paratype male (16.2 mm; ZRC 1964.7.14.4-18), after denudation, showed the lateral margin to be interrupted by 4 notches (hence 5 teeth) (Figs 2J, 6A, E), the posterior two being inconspicuously defined by the last notch. 

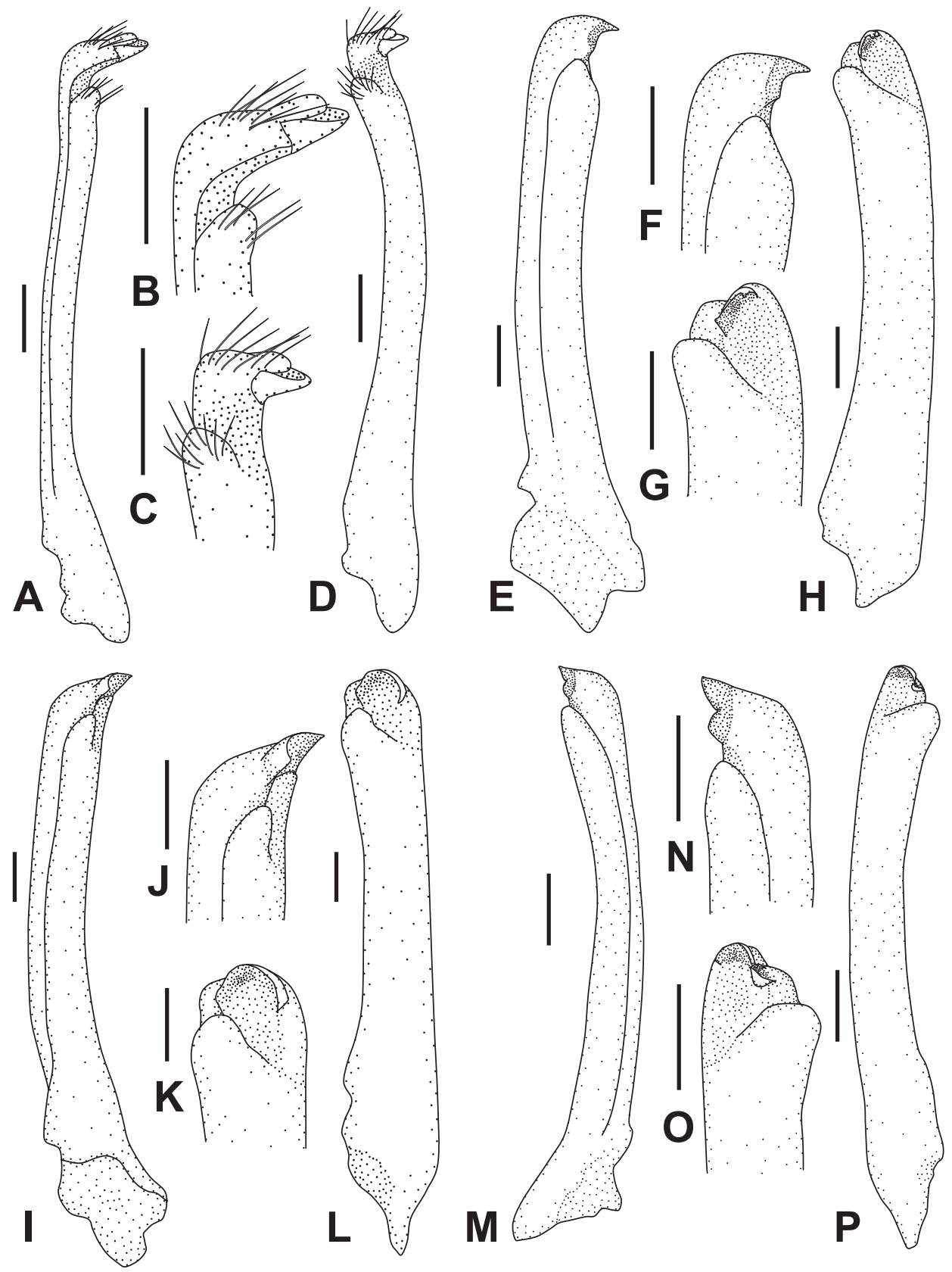

Figure 7. Metaplax elegans De Man, 1888 (A-D NCHUZOOL 15496, male, $12.7 \mathrm{~mm}$ ), right G1; M. longipes Stimpson, 1858 (E-H ZRC 2019.0581, male, 14.9 mm), right G1; M. sheni Gordon, 1930 (I-L NCHUZOOL 15466, male, $9.9 \mathrm{~mm}$ ), right G1; and M. tredecim Tweedie, 1950 (M-P paratype, ZRC 1964.7.14.4-18, $16.2 \mathrm{~mm})$, left G1. Scale bars: $0.5 \mathrm{~mm}$ (A-H, M-P); $0.2 \mathrm{~mm}$ (I-L). 
As mentioned above, two forms, differing in the number of tubercles or lobes on the infraorbital ridge, were recognized in specimens identified with $M$. longipes by Dai et al. (1986) and Dai and Yang (1991). We confirmed that specimens from the study area, characterized by the possession of about 17 tubercles or lobes closely represent $M$. tredecim. There is little doubt that the material studied by Dai et al. (1986) and Dai and Yang (1991) included two species, M. longipes and M. tredecim.

Chertoprud et al. (2012) recorded " $M$. longipes" from Nha Phu, southeastern Vietnam. However, given the infraorbital ridge with 17 tubercles and the chelipeds with the length of palm/the length of dactyl ratio about 1.5 (estimated from their plate $47 \mathrm{~F}$ on page 295), this record is suspected to represent M. tredecim instead (see Table 2).

\section{Note on the number of infraorbital tubercles and lobes}

As one of the major morphological features for the identification of species of Metaplax species, the number of lobes and granules along both infraorbital ridges, which are in all cases sexually dimorphic, differs substantially among species. The following range indicate the number of these lobes and tubercles of both sexes (with the exception of $M$. sheni for which only males were collected), with differences between left and right ridges placed in brackets: in M. elegans 46-61 (0-5) for males and 33-42 (0-3) for females, $M$. longipes 7-13 (0-2) for males and 14-22 (0-2) for females, $M$. sheni 16-20 (0-2) for males, and M. tredecim 13-20 (0-3) for males and 20-27 (0-3) for females (Table 2; Fig. 8). Tubercle counts overlap slightly in specimens of both sexes in $M$. longipes and $M$. tredecim (13 in males and 20-22 in females) and completely in male specimens of $M$. sheni (16-20) and M. tredecim (13-30). Comparing sexes, $M$. longipes and $M$. tredecim counts for males are less than females, but the reverse is true for M. elegans. These figures, however, do not show a clear trend in relation to body size (Table 2; Fig. 8).

\section{Molecular analyses}

The molecular analysis of the COI marker included 22 specimens of Metaplax, with 13 haplotypes (Table 1). The phylogenetic reconstruction (Fig. 9) shows four wellsupported clades, which could correspond to the four species treated in this study. It is obvious that only one clade is represented by specimens of $M$. longipes from South China and specimens from the type locality of M. takahasii (Danshuei, Taiwan). Metaplax longipes and M. tredecim are in sister-relation, and the two species and $M$. sheni form a main clade. Metaplax elegans is distant from other species of Metaplax.

The mean pairwise nucleotide divergence with K2P distances and bp differences of haplotypes of the four species are shown in Table 3. The intraspecific K2P nucleotide divergence of $M$. elegans $(\leq 1.86 \%)$ is higher than that of other species $(\leq 0.92 \%)$. The interspecific divergences among the four species are $\geq 15.87 \%$. 


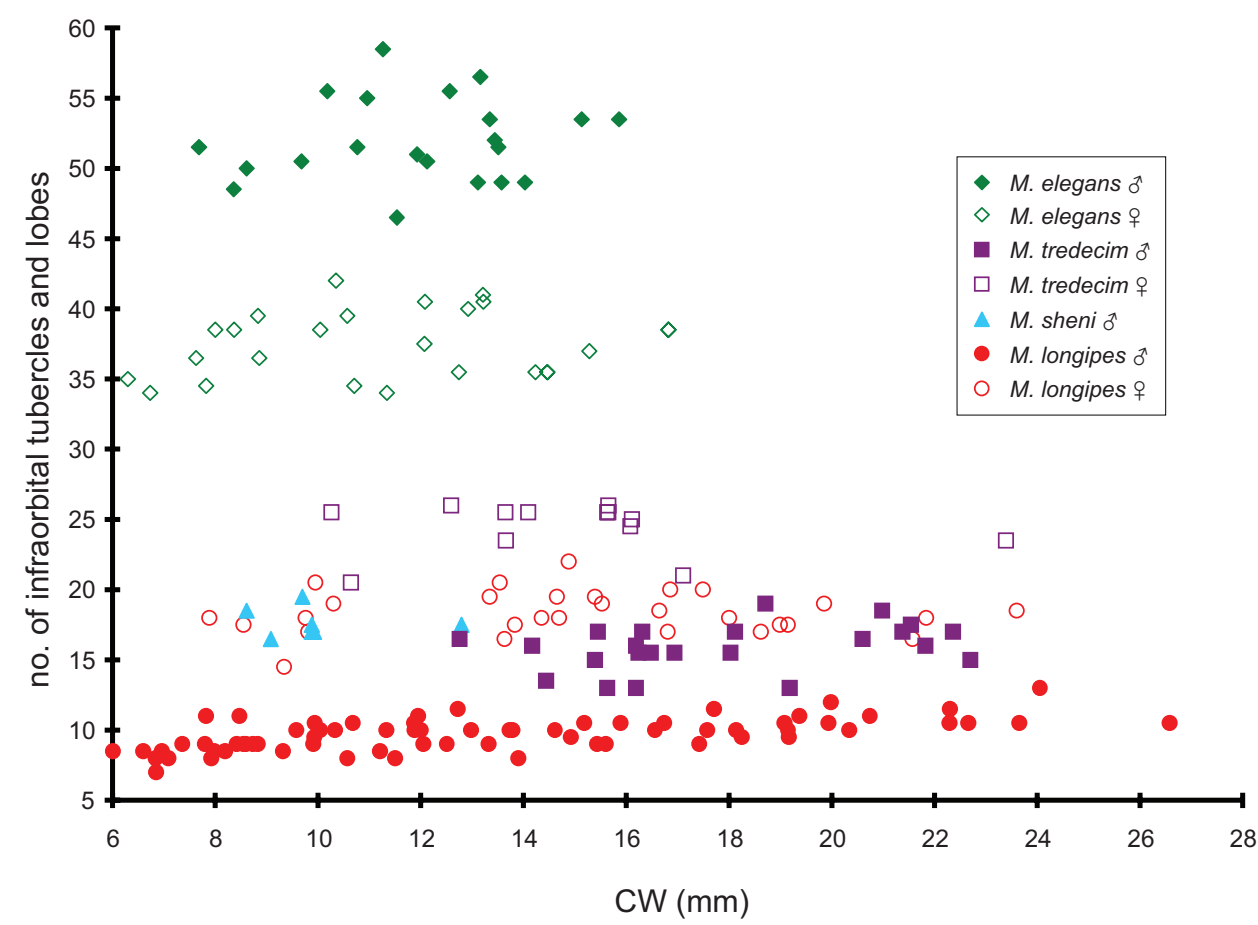

Figure 8. The number of infraorbital tubercles and lobes plotted as a function of carapace width (CW) of Metaplax elegans De Man, 1888, M. longipes Stimpson, 1858, M. sheni Gordon, 1930, and M. tredecim Tweedie, 1950.

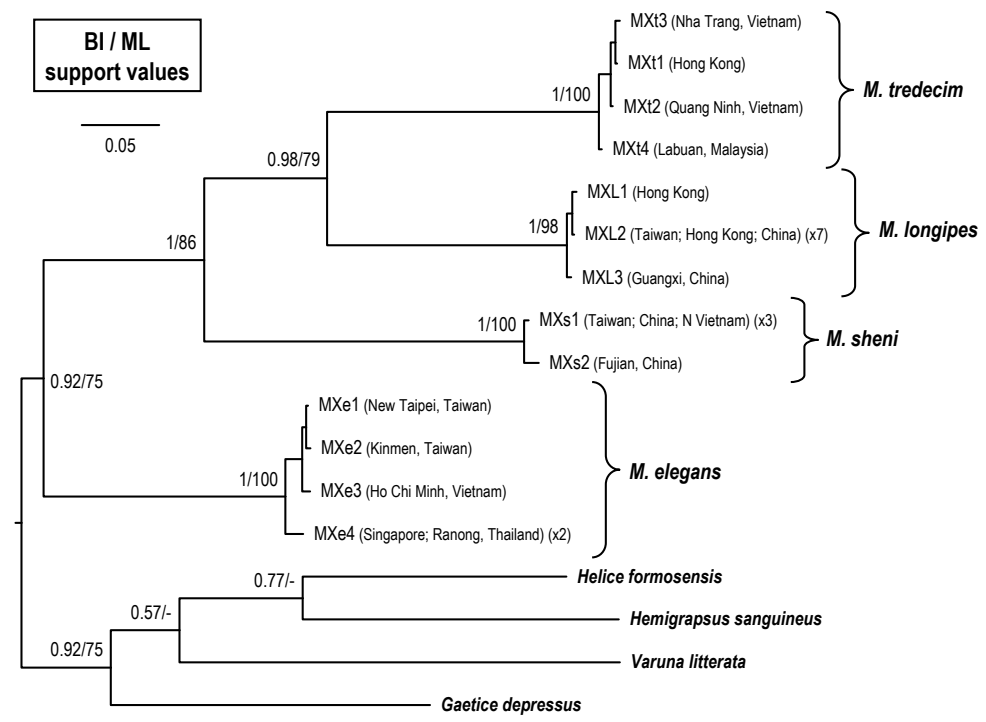

Figure 9. A Bayesian inference (BI) tree for Metaplax elegans De Man, 1888, M. longipes Stimpson, 1858, M. sheni Gordon, 1930, and M. tredecim Tweedie, 1950, and the outgroups, based on the cytochrome c oxidase subunit I (COI) gene. Probability values at the nodes represent support values for BI and maximum likelihood (ML). For haplotype names, see Table 1. 
Table 3. Matrix of percentage pairwise nucleotide divergence with K2P distance (lower left) and mean number of differences (upper right) based on COI within and between species of Metaplax from East Asia and northern Vietnam (see Table 1). Values of range are shown in parentheses.

\begin{tabular}{l|c|c|c|c|c|c}
\hline \multirow{2}{*}{} & \multicolumn{2}{|c|}{ Intraspecific } & \multicolumn{3}{c}{ Interspecific } \\
\cline { 2 - 7 } & $\begin{array}{c}\text { nucleotide } \\
\text { divergence }\end{array}$ & $\begin{array}{c}\text { Mean } \\
\text { nucleotide } \\
\text { difference }\end{array}$ & M. elegans & M. longipes & M. sheni & M. tredecim \\
\hline M. elegans & $1.21(0-1.86)$ & $7.8(0-12)$ & & $106.47(104-108)$ & $102(98-108)$ & $110.35(107-112)$ \\
\hline M. longipes & $0.1(0-0.46)$ & $0.67(0-3)$ & $18.36(17.86-18.67)$ & & $102(101-103)$ & $97.75(93-101)$ \\
\hline M. sheni & $0.46(0-0.92)$ & $3(0-6)$ & $17.5(16.7-18.7)$ & $17.5(17.3-17.71)$ & & $104.44(102-106)$ \\
\hline M. tredecim & $0.48(0.15-0.92)$ & $3.17(1-6)$ & $19.1218 .45-19.45)$ & $16.8(15.87-17.45)$ & $17.99(17.51-18.3)$ & \\
\hline
\end{tabular}

\section{Discussion}

In this study, based on morphological and molecular evidences, we resolve the taxonomic confusions and updated the distribution of Metaplax species from East Asia and northern Vietnam. The presence of four species, viz., M. elegans, M. longipes, M. sheni, and $M$. tredecim are confirmed, and it is verified that $M$. takahasii is conspecific with $M$. longipes, and thus synonymized.

With regard to the number of infraorbital tubercles and lobes, despite elaborate sexual dimorphism among varunid species, serve as a reliable morphological feature in identifying Metaplax species (cf. Table 2), whereas the numbers of $M$. elegans substantially exceed those of congeners (Fig. 8). The numbers of infraorbital tubercles of the Helicel Chasmagnathus complex (Varunidae) are also used for species identification (K. Sakai et al. 2006), and likewise for species of Helicana K. Sakai \& Yatsuzuka, 1980, all supported by genetic evidences. However, three species belong to the "Helice latimera complex" under Helice De Haan, 1833, with varying ranges of tubercle count, were shown to be otherwise (Shih and Suzuki 2008; $\mathrm{Ng}$ et al. 2018). The latter case implied H. latimera Parisi, 1918; H. formosensis Rathbun, 1931; and H. tientsinensis Rathbun, 1931 might well belong to a single species, as discussed in $\mathrm{Ng}$ et al. (2018). This ambiguity of specific delimitation requires further morphological and developmental investigations.

Phylogenetic relationships in the genus Metaplax or among genera of the Varunidae are far from settled. Monophyly of Metaplax has not yet been confirmed. Moreover, despite various recent research effort employing even complete mitochondrial sequences, the sister group of Metaplax remains unclear (Kitaura et al. 2002; Chen et al. 2019; Liu et al. 2019), which is probably due to the limited genera sampled in phylogenetic analyses.

In our study, the four species of Metaplax can be separated by the COI marker with a minimum interspecific distance of $17.5 \%$, which is higher than that of most other crab species (see Chu et al. 2015). The phylogenetic tree based on COI (Fig. 9) showed $M$. longipes and $M$. tredecim as sister species, and both species form a clade that is sister to M. sheni, whereas M. elegans is sister to the three as a whole. The phylogenetic relationships of the four species are also consistent with the number of infraorbital tubercles and lobes, i.e., $M$. longipes and $M$. tredecim, have the fewest number of these structures; $M$. sheni has moderate number; and $M$. elegans has the greatest number (Table 2; Fig. 8). This implies the number of infraorbital tubercles is possibly higher in 
the ancestral form, becoming reduced in successive clades. More species of this genus, however, should be included in the future to test this hypothesis.

Species of Metaplax are mainly distributed in the tropical and subtropical continental regions, in muddy and muddy sand habitats, always accompanied by mangroves (Sakai 1939, 1976; Dai et al. 1986; Dai and Yang 1991). It has been suggested that the pattern of geographical distributions agrees with the "continental type" of fiddler crabs, in contrast with the "oceanic type" mainly inhabited on islands (cf. Shih et al. 2010, 2016; Shih 2012). This also explains why no East Asian species of Metaplax are recorded from Korea, the main islands of Japan, the Ryukyu islands, and eastern Taiwan. The habitat preferred by species of Metaplax is suggested to be related to physiological constraints (e.g., food, temperature, salinity, etc.; Curtis and McGaw 2012; Theuerkauff et al. 2018). Understanding of the population structure may help reveal larval dispersal in the region of East Asia and northern South China Sea (Chan et al. 2007; Shih et al. 2015; Wang et al. 2015; Chai et al. 2017).

The results of this study clarify the biogeographic distribution of three species (Fig. 1). With $M$. takahasii synonymized with $M$. longipes, the distribution of $M$. longipes stretches from western Taiwan (including Matsu and Kinmen) to China (from Jiangsu to Guangxi) and northern Vietnam. Metaplax sheni is found in China (Zhejiang and Fujian), Taiwan (Kinmen), Vietnam, and Malay Peninsula (including Singapore); and the known range of $M$. tredecim include South China (Hainan and Hong Kong), Vietnam, and northern Borneo.

\section{Acknowledgements}

This study was supported by a grant from the Ministry of Science and Technology (MOST 105-2621-B-005-002-MY3), Executive Yuan, Taiwan, to HTS. We wish to thank Pei-Yi Hsu, Hong-Mei Zhu, Thanh Son Nguyen, Jian Chen, Fan-Qin Liu, JinYan Zhai, and Wei-Jen Lin for helping specimen collection in the field; Takehiro Sato for helping check and take photographs of specimens in Kanagawa Prefectural Museum of Natural History; and P.-Y. Hsu for some of the molecular work. We acknowledge the subject editor Sammy De Grave, Shane Ahyong, and Tomoyuki Komai, who greatly improved the manuscript.

\section{References}

Alcock A (1900) Materials for a carcinological fauna of India. No. 6. The Brachyura Catometopa, or Grapsoidea. Journal of the Asiatic Society of Bengal 69(2): 279-456. https://doi. org/10.5962/bhl.title.15344

Beinlich Bv, Polivka R (1989) Zur optischen und vibratorischen Balz von Metaplax crenulata (Gerstaecker, 1856) (Crustacea, Brachyura, Grapsidae). Zoologischer Anzeiger 223: 157-164. https://doi.org/10.5962/bhl.title.660111 
Chai CJ, Esa YB, Ismail MFS, Kamarudin MS (2017) Population structure of the blue swimmer crab Portunus pelagicus in coastal areas of Malaysia inferred from microsatellites. Zoological Studies 56: 26. https://doi.org/10.6620/ZS.2017.56-26

Chakraborty SK, Choudhury A (1994) Population ecology of Metaplax intermedia (Brachyura: Grapsidae) of Sagar Island, Sundarbans, India. Proceedings of the Zoological Society, Calcutta 47: 41-45.

Chan BKK, Tsang LM, Chu KH (2007) Morphological and genetic differentiation of the acorn barnacle Tetraclita squamosa (Crustacea, Cirripedia) in East Asia and description of a new species of Tetraclita. Zoologica Scripta 36: 79-91. https://doi.org/10.1111/j.14636409.2007.00260.x

Chen JQ, Xing YH, Yao WJ, Xu X, Zhang CL, Zhang ZH, Liu Q (2019) Phylomitogenomics reconfirm the phylogenetic position of the genus Metaplax inferred from the two grapsid crabs (Decapoda: Brachyura: Grapsoidea). PLoS ONE 14: e0210763. https://doi. org/10.1371/journal.pone.0210763

Chen YS (1991) Brachyura (Brachyrhyncha). In: Wei CD, Chen YS (Eds) Fauna of Zhejiang - Crustacea. Zhejiang Science and Technology Publishing House, Hangzhou, Zhejiang, China, 349-387, 402-443. [In Chinese]

Chertoprud ES, Spiridonov VA, Marin IN, Mokievsky VO (2012) Brachyuran crabs (Crustacea Decapoda Brachyura) of the mangrove intertidal zone of southern Vietnam. In: Britayev TA, Pavlov DS (Eds) Benthic Fauna of the Bay of Nhatrang, Southern Vietnam. KMK Scientific Press Ltd., Moscow, Vol. 2, 258-295.

Choy SC, Booth WE (1994) Prolonged inundation and ecological changes in an Avicennia mangrove: implications for conservation and management. Hydrobiologia 285: 237-247. https://doi.org/10.1007/BF00005670

Chu KH, Schubart CD, Shih HT, Tsang LM (2015) Genetic diversity and evolution of Brachyura. In: Castro P, Davie PJF, Guinot D, Schram FR, von Vaupel Klein JC (Eds) Treatise on Zoology - Anatomy, Taxonomy, Biology - The Crustacea, complementary to the volumes translated from the French of the Traité de Zoologie. Brill. Leiden, 9(C)(II), Decapoda: Brachyura (Part 2), 775-820. https://doi.org/10.1163/9789004190832_016

Curtis DL, McGaw IJ (2012) Salinity and thermal preference of Dungeness crabs in the lab and in the field: Effects of food availability and starvation. Journal of Experimental Marine Biology and Ecology 413: 113-120. https://doi.org/10.1016/j.jembe.2011.12.005

Dai AY, Yang SL (1991) Crabs of the China Seas. China Ocean Press, Beijing, 608 pp. [74 pls]

Dai AY, Yang SL, Song YZ, Chen GX (1986) Crabs of the China seas. China Ocean Press, Beijing, 568 pp. [74 pls] [In Chinese]

Davie PJF (1992) A new species and new records of intertidal crabs (Crustacea: Brachyura) from Hong Kong. In: Morton B (Ed.) The Marine Flora and Fauna of Hong Kong and Southern China III. Proceedings of the Fourth International Marine Biological Workshop: The marine flora and fauna of Hong Kong and southern China, Hong Kong, 11-29 April 1989. Hong Kong University Press, Hong Kong, 345-359.

Davie PJF, Nguyen VX (2003) A new species of Metaplax (Crustacea: Brachyura: Varunidae: Cyclograpsinae) from Vietnam. Raffles Bulletin of Zoology 51: 379-386. 
Dev Roy MK (2008) An annotated checklist of mangrove and coral reef inhabiting brachyuran crabs of India. Records of the Zoological Survey of India, Occasional Paper 289: 1-212.

Dev Roy MK, Bhadra S (2001) Brachyuran crabs (Crustacea: Decapoda: Brachyura). In: Zoological Survey of India (Ed.) Estuarine Ecosystem Series 4: Fauna of Godavari Estuary. Zoological Survey of India. Kolkata, 35-54.

Dev Roy MK, Bhadra S (2011) Brachyuran crabs (Crustacea: Decapoda: Brachyura). In: Zoological Survey of India (Ed.) Fauna of Tamil Nadu, State Fauna Series 17(2). Zoological Survey of India. Kolkata, India, 109-269.

Evans AC (1967) Syntypes of Decapoda described by William Stimpson and James Dana in the collections of the British Museum (Natural History). Journal of Natural History 1: 399-411. https://doi.org/10.1080/00222936700770391

Folmer O, Black M, Hoeh W, Lutz R, Vrijenhoek R (1994) DNA primers for amplification of mitochondrial cytochrome c oxidase subunit I from diverse metazoan invertebrates. Molecular Marine Biology and Biotechnology 3: 294-299.

Fransen CHJM, Holthuis LB, Adema JPHM (1997) Type-catalogue of the decapod Crustacea in the collections of the Nationaal Natuurhistorisch Museum, with appendices of pre-1900 collectors and material. Zoologische Verhandelingen, Leiden 311: 1-344. [figs 1-79]

Fukui Y, Wada K, Wang CH (1989) Ocypodidae, Mictyridae and Grapsidae (Crustacea: Brachyura) from some coasts of Taiwan. Journal of Taiwan Museum 42: 225-238.

Gee NG (1926) Tentative list of Chinese decapod Crustacea. Lingnaam Agricultural Review 3(2): 156-166.

Gordon I (1930) Seven new species of Brachyura from the coasts of China. Annals and Magazine of Natural History (10)6: 519-525. https://doi.org/10.1080/00222933008673240

Gordon I (1931) Brachyura from the coasts of China. Journal of the Linnean Society (Zoology) 38: 525-558. https://doi.org/10.1111/j.1096-3642.1931.tb02365.x

Ho PH, Hung MS (1997) Seashore Crabs of Hsin-Chu City. Hsinchu City Government, Hsinchu City, 122 pp. [In Chinese]

Horikawa Y (1940) A list of Formosan crabs. Scientific Taiwan 8: 21-31. [In Japanese]

Huang ZG (1994) Marine Species and their Distributions in China's seas. China Ocean Press, Beijing, 764 pp. [In Chinese]

Huang ZG (2008) Marine Species and their Distributions in China. China Ocean Press, Beijing, 1191 pp. [In Chinese]

International Code of Zoological Nomenclature (1999) International Commission of Zoological Nomenclature. Fourth Edition. Adopted by the XXI General Assembly of the International Union of Biological Sciences. International Trust for Zoological Nomenclature, in association with the British Museum (Natural History), London, 338 pp.

Jeng CH, Ling HJ, Wang MF, Jan CP (1998) Common Seashore Crabs of Taichung. Yungan Primary School, Taichung, Taiwan, 92 pp. [In Chinese]

Jeng CH, Wang MF (2000) A Field Guide of Crabs. Taichung Nature Research Society, Taichung, 48 pp. [In Chinese]

Kimura M (1980) A simple method for estimating evolutionary rates of base substitutions through comparative studies of nucleotide sequences. Journal of Molecular Evolution 16: 111-120. https://doi.org/10.1007/BF01731581 
Kitaura J, Wada K, Nishida M (2002) Molecular phylogeny of grapsoid and ocypodoid crabs with special reference to the genera Metaplax and Macrophthalmus. Journal of Crustacean Biology 22: 682-693. https://doi.org/10.1651/0278-0372(2002)022[0682:MPOGAO]2.0.CO;2

Koelbel K (1897) Rákok. In: Széchenyi B (Ed.) Keletázsiai utjának tudományos. Eredménye, 1877-1880 [Scientific results of the East Asian Passage, 1877-1880]. KFEK Bizományában, Budapest, Vol. 2, 707-718.

Kosuge T, Wada K, Trong PD (1997) Crab distribution in the Cam River estuary, Haiphong, northern Vietnam. In: Anh PN, Brands JT, Hong PN (Eds) National workshop on the relationship between mangrove rehabilitation and coastal aquaculture in Vietnam. CRES \& ACTMANG, Hanoi, 178-184.

Kumar S, Stecher G, Li M, Knyaz C, Tamura K (2018) MEGA X: Molecular Evolutionary Genetics Analysis across computing platforms. Molecular Biology and Evolution 35: 15471549. https://doi.org/10.1093/molbev/msy096

Kuo CY (1995) Natural Trip of Taiwanese Mangroves. Bigtrees Co., Taipei, 198 pp. [In Chinese] Lanfear R, Frandsen PB, Wright AM, Senfeld T, Calcott B (2017) PartitionFinder 2: new methods for selecting partitioned models of evolution for molecular and morphological phylogenetic analyses. Molecular Biology and Evolution 34: 772-773. https://doi.org/10.1093/ $\mathrm{molbev} / \mathrm{msw} 260$

Lee JH (2001) A Field Guide to Crabs in Taiwan. Bigtrees Co., Taipei, 174 pp. [In Chinese]

Lee JH, Chiu YW, Wu TT, Tseng LK, Huang YC (2013) A Field Guide to the Shrimps, Crabs and Shells of Taijiang National Park. Taijiang National Park, Tainan City, 239 pp. [In Chinese]

Lee JH, Tung SC (2000) Crabs of Tainan County coast. Tainan County Government and Kung San Institute of Technology, Tainan, 72 pp. [In Chinese]

Lee SY, Leung V (1999) The brachyuran fauna of the Mai Po marshes Natural Reserve and Deep Bay, Hong Kong. In: Lee SY (Ed.) The Mangrove Ecosystem of Deep Bay and the Mai Po marshes, Hong Kong. Proceedings of the Mangrove Workshop on the Mangrove Ecosystem of Deep Bay and Mai Po Marshes, Hong Kong. Hong Kong University Press, Hong Kong, 57-82.

Lin CC (1949) A catalogue of brachyurous Crustacea of Taiwan. Quarterly Journal of the Taiwan Museum 2: 10-33.

Liu HC, Wang CH (2010) Taiwan Coastal Wetland Crabs. Wild Bird Society of Taipei, Taipei, 79 pp. [In Chinese]

Liu WL, He WS (2007) The Benthic Macro-Invertebrates in the Yangtze Estuary. Shanghai Scientific \& Technical Publishers, Shanghai, 203 pp. [In Chinese]

Liu Y, Yang TT, Xin ZZ, Liu QN, Zhang DZ, Tang BP (2019) The complete mitochondrial genome sequence of Metaplax longipes (Grapsoidea: Varunidae). Mitochondrial DNA Part B 4: 1280-1282. https://doi.org/10.1080/23802359.2019.1574626

Macnae W (1963) A general account of the fauna and flora of mangrove swamps and forests in the Indo-West-Pacific Region. Advances in Marine Biology 6: 73-270. https://doi. org/10.1016/S0065-2881(08)60438-1

Man JGD (1888) Report on the podophthalmous Crustacea of the Mergui Archipelago, collected for the Trustees of the Indian Museum, Calcutta, by Dr. John Anderson, F.R.S., Su- 
perintendent of the Museum. Journal of the Linnean Society (Zoology) 22: 1-311. https:// doi.org/10.1111/j.1096-3642.1888.tb01455.x

Muraoka K (1998) Catalogue of the brachyuran and anomuran crabs donated by Prof. Dr. Tune Sakai to the Kanagawa Prefectural Museum. Catalogue of the Collection in the Kanagawa Prefectural Museum of Natural History 11: 1-67. [pls 1-16] [In Japanese]

Naderloo R (2011) Grapsoid crabs (Decapoda: Brachyura: Thoracotremata) of the Persian Gulf and the Gulf of Oman. Zootaxa 3048: 1-43. https://doi.org/10.11646/zootaxa.3048.1.1

Naderloo R (2017) Atlas of crabs of the Persian Gulf. Springer, Cham, Switzerland, 444 pp. https://doi.org/10.1007/978-3-319-49374-9

Naiyanetr P (2007) Checklist of Crustacean Fauna in Thailand (Decapoda, Stomatopoda, Anostraca, Myodocopa and Isopoda). Office of Natural Resources and Environmental Policy and Planning, Bangkok, 196 pp.

Ng NK, Naruse T, Shih HT (2018) Helice epicure, a new species of varunid mud crab (Brachyura, Decapoda, Grapsoidea) from the Ryukyus, Japan. Zoological Studies 57: 15. https:// doi.org/10.6620/ZS.2018.57-15

Ng PKL, Davie PJF (2002) A checklist of the brachyuran crabs of Phuket and western Thailand. Phuket Marine Biological Center Special Publication 23: 369-384.

Ng PKL, Guinot D, Davie PJF (2008) Systema Brachyurorum: Part I. An annotated checklist of extant brachyuran crabs of the world. Raffles Bulletin of Zoology, Supplement 17: 1-296.

Ng PKL, Shih HT, Ho PH, Wang CH (2017) An updated annotated checklist of brachyuran crabs from Taiwan (Crustacea: Decapoda). Journal of the National Taiwan Museum 70: 1-208. https://doi.org/10.6532/JNTM.201712_70(3;4).01

Ng PKL, Sivasothi N (1999) A Guide to the Mangroves of Singapore - Volume 1: The ecosystem and plant diversity. Singapore Science Centre, Singapore, $160 \mathrm{pp}$.

Ng PKL, Wang CH, Ho PH, Shih HT (2001) An annotated checklist of brachyuran crabs from Taiwan (Crustacea: Decapoda). National Taiwan Museum Special Publication Series 11: 1-86. https://doi.org/10.6532/JNTM.201712_70(3;4).01

Rath S, Dev Roy MK (2008) Brachyuran crabs (Crustacea: Decapoda: Brachyura). In: Zoological Survey of India (Ed.) Fauna of Krishna Estuary, Estuarine Ecosystem, Series 5. Zoological Survey of India, Kolkata, 43-81. [pls 1-6]

Rathbun MJ (1931) New and rare Chinese crabs. Lingnan Science Journal 8: 75-125.

Ronquist F, Huelsenbeck JP, Teslenko M, Nylander JAA (2005) MrBayes 3.2 Manual. http:// mrbayes.csit.fsu.edu/manual.php

Ronquist F, Teslenko M, van der Mark P, Ayres DL, Darling A, Höhna S, Larget B, Liu L, Suchard MA, Huelsenbeck JP (2012) MRBAYES 3.2: efficient Bayesian phylogenetic inference and model choice across a large model space. Systematic Biology 61: 539-542. https://doi.org/10.1093/sysbio/sys029

Sakai K, Türkay M, Yang SL (2006) Revision of the Helice/Chasmagnathus complex (Crustacea: Decapoda: Brachyura). Abhandlungen der Senckenbergischen Naturforschenden Gesellschaft 565: 1-76.

Sakai T (1939) Studies on the Crabs of Japan - IV. Brachygnatha, Brachyrhyncha. Vol. 3, 365-741.[pls 42-111] 
Sakai T (1940) Bio-geographic review on the distribution of crabs in Japanese waters. Records of Oceanographic Works in Japan 11: 27-63.

Sakai T (1976) Crabs of Japan and the Adjacent Seas. Kodansha Ltd., Tokyo, 773 pp. [251 pls] Shen CJ (1940a) On the collections of crabs of South China. Bulletin of the Fan Memorial Institute of Biology (Zoology) 10: 69-104.

Shen CJ (1940b) The brachyuran fauna of Hong Kong. Journal of the Hong Kong Fisheries Research Station 1: 211-242.

Shen CJ, Dai AY (1964) Illustrations of Animals in China (Crustacea part II). Science Press, Beijing, 142 pp. [In Chinese]

Shih HT (2012) Distribution of fiddler crabs in East Asia, with a note on the effect of the Kuroshio Current. Kuroshio Science 6: 83-89.

Shih HT, Lee JH, Ho PH, Liu HC, Wang CH, Suzuki H, Teng SJ (2016) Species diversity of fiddler crabs, genus $U_{c a}$ Leach, 1814 (Crustacea: Ocypodidae), from Taiwan and adjacent islands, with notes on the Japanese species. Zootaxa 4083: 57-82. https://doi. org/10.11646/zootaxa.4083.1.3

Shih HT, Ng PKL, Fang SH, Chan BKK, Wong KJH (2010) Diversity and distribution of fiddler crabs (Brachyura: Ocypodidae: $U c a$ ) from China, with new records from Hainan Island in the South China Sea. Zootaxa 2640: 1-19. https://doi.org/10.11646/zootaxa.2640.1.1

Shih HT, Saher NU, Kamrani E, Ng PKL, Lai YC, Liu MY (2015) Population genetics of the fiddler crab Uca sindensis (Alcock, 1900) (Crustacea: Brachyura: Ocypodidae) from the Arabian Sea. Zoological Studies 54: 1. https://doi.org/10.1186/s40555-014-0078-3

Shih HT, Suzuki H (2008) Taxonomy, phylogeny, and biogeography of the endemic mudflat crab Helice/Chasmagnathus complex (Crustacea: Brachyura: Varunidae) from East Asia. Zoological Studies 47: 114-125.

Shih JT, Lue KY, Wang CH (1991) Crab fauna and the activities of ten crab species in Tanshui mangrove swamp of Taiwan. Annual of Taiwan Museum 34: 121-140. [In Chinese]

So SNH, Lui HTH (2007) Small wetland creatures. HK Discovery Limited, Hong Kong, 80 pp.

Stamatakis A (2006) RAxML-VI-HPC: maximum likelihood-based phylogenetic analyses with thousands of taxa and mixed models. Bioinformatics 22: 2688-2690. https://doi. org/10.1093/bioinformatics/btl446

Stimpson W (1858) Prodromus descriptionis animalium evertebratorum, quae in Expeditione ad Oceanum Pacificum Septentrionalem, a Republica Federata missa, Cadwaladaro Ringgold et Johanne Rodgers Ducibus, observavit et descripsit. Pars V. Crustacea Ocypodoidea. Proceedings of the Academy of Natural Sciences of Philadelphia 10: 93-110. https://doi. org/10.5962/bhl.title.51447

Stimpson W (1907) Report on the Crustacea (Brachyura and Anomura) collected by the North Pacific Exploring Expedition, 1853-1856. Smithsonian Miscellaneous Collections 49: 1-240. [pls 1-26] https://doi.org/10.5962/bhl.title.51448

Tan CGS, Ng PKL (1994) An annotated checklist of mangrove brachyuran crabs from Malaysia and Singapore. Hydrobiologia 285: 75-84. https://doi.org/10.1007/BF00005655

Tesch JJ (1918) The Decapoda Brachyura of the Siboga Expedition. I. Hymenosomidae, Retroplumidae, Ocypodidae, Grapsidae and Gecarcinidae. Siboga-Expeditie 39(c): 1-148. [pls 1-6] https://doi.org/10.5962/bhl.title.10267 
Theuerkauff D, Rivera-Ingraham GA, Roques JAC, Azzopardi L, Bertini M, Lejeune M, Farcy E, Lignot JH, Sucré E (2018) Salinity variation in a mangrove ecosystem: A physiological investigation to assess potential consequences of salinity disturbances on mangrove crabs. Zoological Studies 57: 36. https://doi.org/10.6620/ZS.2018.57-36

Tweedie MWF (1936) On the crabs of the family Grapsidae in the collection of the Raffles Museum. Bulletin of the Raffles Museum, Singapore 12: 44-70.

Tweedie MWF (1950) Grapsoid crabs from Labuan and Sarawak. Sarawak Museum Journal 5: 338-369.

Wang CH (2003) Crabs. In: Chen CP, Wu CY (Eds) Kimnen coastal creatures guide. Kinmen County Government, Kinmen, 86-111. [In Chinese]

Wang CH, Liu HC (1996a) Common Seashore Crabs of Taiwan. Taiwan Museum, Taipei, 136 pp. [In Chinese]

Wang CH, Liu HC (1996b) Estuarine Crabs of Taiwan. Wild Bird Society of Kaohsiung, Kaohsiung, 113 pp. [In Chinese]

Wang CH, Liu HC (1996c) Preliminary investigations of the crab diversity of Wu-Jiang estuary mangrove area in Kinmen. Proceedings of a Conference on Mangrove Ecology. Taiwan Endemic Species Institute, Nantou, 223-229. [In Chinese]

Wang CH, Liu HC (1998a) Common Seashore Crabs of Taiwan (2 $2^{\text {nd }}$ edn). Taiwan Museum, Taipei, 136 pp. [In Chinese]

Wang CH, Liu HC (1998b) Mangrove crabs of Taiwan. In: Huang S, Shih JT, Hsueh ML (Eds) Mangroves of Taiwan. Taiwan Endemic Species Research Institute, Nantou, 94-150. [In Chinese]

Wang CH, Liu HC (2003) Common Seashore Crabs of Taiwan ( ${ }^{\text {rd }}$ edn). Taiwan Museum, Taipei, 136 pp. [In Chinese]

Wang J, Tsang LM, Dong YW (2015) Causations of phylogeographic barrier of some rocky shore species along the Chinese coastline. BMC Evolutionary Biology 15: 114. https://doi. org/10.1186/s12862-015-0387-0

Yang SL, Chen HL, Jiang W (2008) Brachyura. In: Liu RY (Ed.) Checklist of marine biota of China seas. Science Press, Beijing, 76-810. [In Chinese] 